\section{E-LOGOS}

ELECTRONIC JOURNAL FOR PHILOSOPHY ISSN 1211-0442

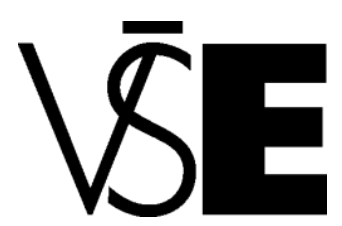

University of Economics

Prague

\title{
Základní struktura Plótínovy
}

metafyziky

Miroslav Vacura

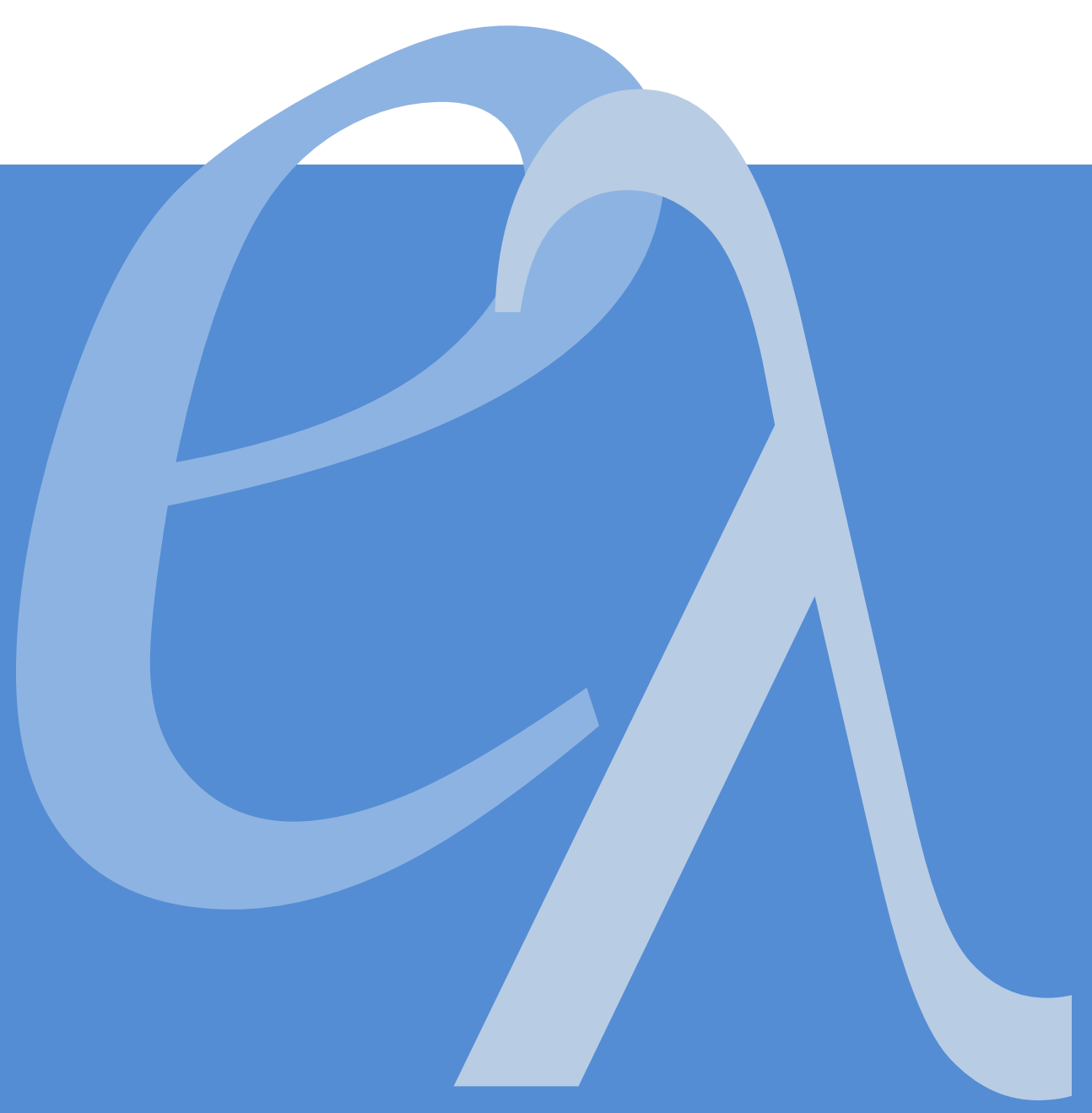




\begin{abstract}
Plotinus' philosophy is exceptionally systematic, however its enormous complexity makes understanding and evaluation difficult. Presented study focuses on exploring fundamental structure of architecture of Plotinus' metaphysics, based on contemporary interpretative commentaries and studies. Taking hierarchical ordering of analyzed metaphysical system as starting point we proceed by analyzing character of each of metaphysical levels and its relation to other components of Plotinus' system.
\end{abstract}

Keywords: Plotinus' philosophy, metaphysics, ontology.

\title{
Abstrakt
}

Plótínovo filosofické dílo je mimořádně systematické, nicméně jeho značný rozsah a složitost znesnadňuje celkové pochopení a výklad. V předkládané studii se pokoušíme prozkoumat základní strukturu celé Plótínovy metafyzické stavby, v souladu s nejnovějšími interpretačními poznatky. Východiskem je hierarchické uspořádání celého systému, přičemž ve výkladu postupujeme po metafyzických úrovních a snažíme se charakterizovat jak jejich vlastní povahu, tak vztah k ostatním součástem Plótínova systému.

Klíčová slova: Plótínova filosofie, metafyzika, ontologie. 
Nejvýznamnější z novoplatoniků, Plótínos, ${ }^{1}$ na rozdíl od mnoha jiných filosofů své doby nepsal žádné komentáře a podobně jako Sókratés, Platón a Ammonius Sakkas měl velmi vlažný vztah k filosofování formou psaného textu. Teprve po dekádě přesvědčování se filosof, kterému už bylo v té době přes padesát let, rozhodl k sepsání svých myšlenek. ${ }^{2}$

Plótínos se sám považoval za Platónova věrného pokračovatele a interpreta, který obnovuje jeho učení a brání je proti gnostickému a jiným formám odklonu. ${ }^{3}$ Oproti tomu už Plótínovi současníci oceňovali jeho originalitu a tvưrčí rozvinutí Platónova myšlení. ${ }^{4}$ Plótínos ve své vlastní filosofické práci často vycházel pouze z krátkých pasáží Platónova textu, někdy vytržených z kontextu, a některé části Platónova učení zcela ve své filosofii opomíjí (politickou filosofii, matematiku; naprosto ignoruje snahu najít základní eticky relevantní definice v raných Platónových dialozích) ${ }^{5}$

Ačkoli je Plótínos tedy v první řadě platónským filosofem, v jeho myšlení najdeme mnoho principů převzatých z filosofie Aristotelovy a dalších filosofických škol. I když se proti mnoha z nich vymezoval, nebránilo mu to zakomponovat do svého systému prvky jiných filosofických soustav. Plótínova filosofie, ač vychází z myšlenek jeho předchůdců, tak tvoří vlastní systematickou uzavřenou soustavu, přičemž ve srovnání s jeho originalitou někteří autoři označují práce dalších novoplatoniků za „poznámky pod čarou k Enneadám“. 6

\section{Architektura Plótínovy metafyziky}

Plótínova metafyzika je svou povahou hierarchická, stupňovitá. V jejím základě leží představa více úrovní, vrstev bytí či „řetězce“ bytí. Pokud takto ovšem mluvíme o Plótínově metafyzice, narážíme na omezení našeho jazyka: jak upozorňuje O’Meara, výrazy jako „hierarchie“ či ,ک̌retězec byti““ jsou až pozdějšího data a v Plótínově textu je nenalezneme. Pokud je budeme tedy v souvislosti s Plótínovým systémem používat, musíme si být vědomi limitů jejich významu. Stejný autor pak doporučuje při popisu této hierarchičnosti dávat tam, kde je to možné, před-

\footnotetext{
${ }^{1}$ Plótínos (204/5-270) se narodil pravděpodobně v Egyptě, byl ovšem řeckého vzdělání i kultury, studoval filosofii v Alexandrii, nejprve u několika učitelů, se kterými nebyl spokojen, následně jedenáct let u platónsky orientovaného filosofa jménem Ammonius Sakkas, o němž toho jinak není mnoho známo. Poté se přidal k vojenskému tažení Gordiana III. do Persie, které však bylo neúspěšné, a jen s obtížemi se vrátil do Antiochie. Většinu života pak strávil v Ř́mě, kde vyučoval ve vlastní filosofické škole (Porfyrios. "Vita Plotini". In: Plotinus. The Enneads. London: Larson Publications, 1992 (dále citováno jako Vita Plotini), odd. 3).

${ }^{2}$ Srv. Vita Plotini, odd. 20.

${ }^{3}$ Enneady citujeme podle Plotinus. Enneads I-VI. Překl. A. H. Armstrong. Loeb Classical Library. Cambridge, Massachusetts: Harvard University Press, 1966-1988. (Dále citováno jako Enn.). Proti gnostikům se Plótínos vymezuje například v Enn., s. II.9.6.24-8.

${ }^{4}$ Vita Plotini, odd. 17, 19-20; Richard T. Wallis. Neoplatonism. London: Hackett Publishing, 1972, s. 16.

${ }^{5}$ Ibid., s. 18.

${ }^{6}$ Ibid., s. 93 .
} 


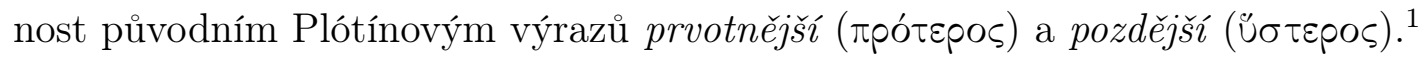

Víme, že v případě Aristotelova rozlišení podstaty a připadků bylo hlavním kritériem, na jehož základě k tomuto rozlišení došlo, to, že případky jsou jsoucna, která jsou přítomna-v jiných, zatímco podstaty jsou jsoucna, která nejsou př́tomna-v jiných, tedy jsou nezávislá. Vztah př́ipadků a podstat je tedy vztahem vzájemné závislosti, podmíněnosti. Bez bytí podstaty nemůže být případek. Pouze tehdy, když už tu je nějaká podstata (např. věc), pak zde může být také případek (např. její vlastnost, kupř́ikladu bělost). Pokud podstata přestane být, přestanou být i všechny případky, které jsou s ní svázány, jsou na ní závislé. Podstata je tak chápána, řečeno Plótínovou terminologií, jako prvotnějši a případek jako pozd-

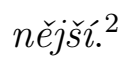

Tento typ odvozenosti a závislosti „co do svého bytí“ má také Plótínos na mysli, když konstruuje svo̊j stupňovitý metafyzický systém, ve kterém za sebou následují vrstvy v pořadí, kde to předchozí, je vždy v tomto smyslu prvotnější, a to následující je pozdějšri. Jedná se tedy o vztah ontologické fundace, založení a závislosti, která se stupňovitě, iterativně opakuje.

Jaké stupně tedy Plótínův metafyzický systém zahrnuje? Vychází ze vztahu duše a těla - už $\mathrm{v}$ jejich případě se můžeme ptát, zdali mezi nimi jde o vztah ontologické závislosti, zdali je jedno z nich prvotnějši a je v ontologickém smyslu základem toho druhého, které na něm závisí. Plótínos ve Enneadě IV.7 uvádí řadu argumentů, ${ }^{3}$ které mají prokázat, že duše je prvotnějši než tělo. Tato úvaha se ve svém plném rozvinutí netýká jen všeho tělesného - materiálního světa, světa těles -, ale také vede k úvahám o povaze samotné duše, o duších v plurálu, jejich druzích a jejich vzájemných vztazích. Vztahu mezi tělesným a duševním je pak věnován text Enneady IV.4-5. Ohledně duševního světa přijímá Plótínos aristotelské učení o různých druzích duše (vegetativní duše rostlin, vnímavá duše živočichů...), ale také Platónovu koncepci světové duše, která jednotlivé individuální duše spoluzahrnuje.

Ovšem duše nemůže podle Plótína stát na nejvyšším stupni ontologické hieararchie, a musíme se proto ptát, zdali není něco prvotnějšího, od čeho by bylo bytí duše odvozeno a na čem by bylo ontologicky závislé. Plótínos, zde opět inspirován Platónem a Aristotelem, odpovídá, že tím ontologicky nadřazeným duši je intelekt. Intelekt (voũs) je ontologicky prvotnějši než duše, ta je na něm co do svého bytí závislá. Pro nesnadnou srozumitelnost pojmu intelekt v tomto kontextu se k jeho stručnému vyložení na následujících stránkách ještě vrátíme. Předběžně mu můžeme rozumět jako Aristotelovu božskému rozumu či Platónově světu idejí.

Ani u intelektu se nelze podle Plótína v tomto typu tázání zastavit, jak činí Aristotelés, pro kterého je božský rozum, prvotní nehybný hybatel, tím, za co

\footnotetext{
${ }^{1}$ Dominic O'Meara. "The hierarchical ordering of reality in Plotinus". In: The Cambridge Companion to Plotinus. Ed. Lloyd P. Gerson. Cambridge: Cambridge University Press, 1996, s. 66 .

${ }^{2}$ Miroslav Vacura. "Systém kategorií u Aristotela". In: E-LOGOS (2009), s. 1-22, s. 4.

${ }^{3}$ Jelikož tento problém není předmětem našeho zájmu, ponecháme jej na tomto místě bez analýzy a komentáře.
} 
již nelze dále jít. Plótínos se však domnívá, že i zde se lze opět zeptat, zdali je něco prvotnějšího, v čem je bytí intelektu založeno. Intelekt, zahrnující určitou mnohost a rozrůzněnost, nemůže spočívat sám v sobě, být nezávislý na čemkoli jiném. Mnohost předpokládá jednotu, jednota je pro Plótína vždy ontologicky prvotnějši než mnohost. Prvotnějšim než intelekt, tím, od čeho je intelekt „,co do svého bytí" odvozen a na čem ontologicky závisí, je Jedno, absolutní nerozrůzněná jednota.

Jedno, jak již z Plótínem zvoleného výrazu vysvítá, nezahrnuje žádnou mnohost či různost. Odpovídá Platónově ideji dobra, která přesahuje všechny ostatní ideje. Plótínovo Jedno stojí mimo ontologický rámec všeho ostatního, stojí „mimo bytí“

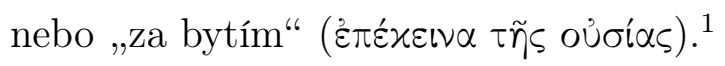

Tyto tři stupně podkládající či zakládající smyslový svět - Duše, Intelekt, Jedno

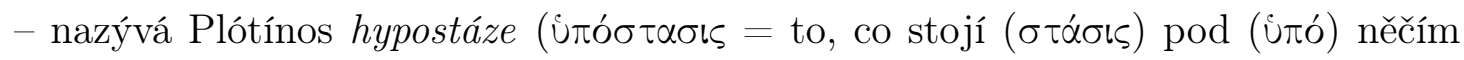
jiným, podkládá jej, základ, fundament). ${ }^{2}$

Základní strukturu Plótínovy metafyziky můžeme zjednodušeně zobrazit na diagramu 1. Při volbě způsobu grafického vyjádření ontologické struktury máme samozřejmě dvě základní možnosti, dané pořadím vertikálního uspořádání. Zde jsme zvolili umístění smyslového světa vertikálně zcela nahoře, naopak Jedno se nachází zcela dole - tímto způsobem se snažíme vyjádřit představu zakládání, kdy jednotlivé hypostáze tvoří hierarchicky uspořádaný podklad smyslového světa. Celek veškerenstva se tak v posledním počátku zakládá v Jednom, ve kterém je vše ontologicky fundováno, ze kterého vše vyvěrá, emanuje (viz dále).

Shrneme-li dosavadní výklad: základ Plótínovy metafyzické koncepce tvoří teo-

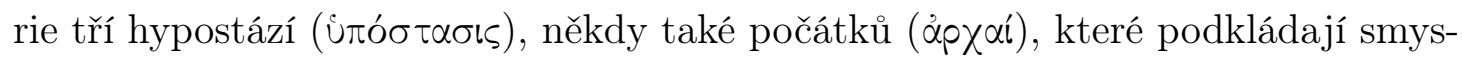
lový, materiální svět. Hierarchické ontologické uspořádání zahrnuje tedy čtyři stupně - tři hypostáze a smyslový svět: ${ }^{3}$

- Jedno (气े $)$

- Intelekt (voũs)

- Duše $(\psi u x \not ́)$

- Smyslový svět

Toto uspořádání je hierarchické především co se týče ontologické podmíněnosti: počátkem a základem všeho je Jedno, Intelekt vychází z Jedna, Duše vychází z Intelektu a smyslový svět přírody je výsledkem působení Duše na látku v souladu

\footnotetext{
${ }^{1}$ Viz např́íklad Enn., s. V.4.1.5. Zde Plótínos navazuje na Platóna, který v šesté knize Ústavy (509b) říká: „Rci tedy, že i předměty poznání mají od dobra nejen to, že jsou poznávány, nýbrž že

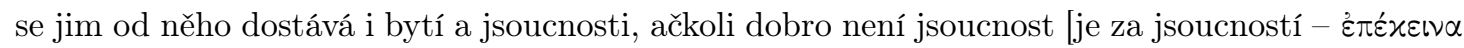

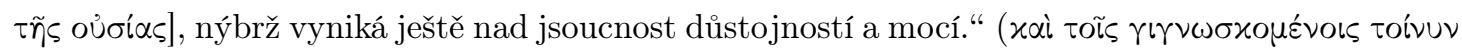

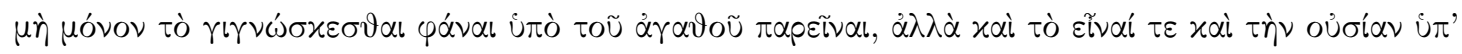

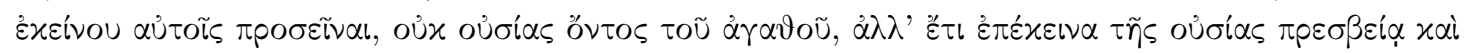

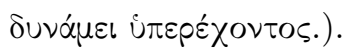

${ }^{2}$ Názvy jednotlivých hypostází (Duše, Intelekt, Jedno) budeme pro rozlišení psát s velkým písmenem na začátku.

${ }^{3}$ Kevin Corrigan. Reading Plotinus : A Practical Introduction to Neoplatonism. West Lafayette: Purdue University Press, 2005, s. 7.
} 


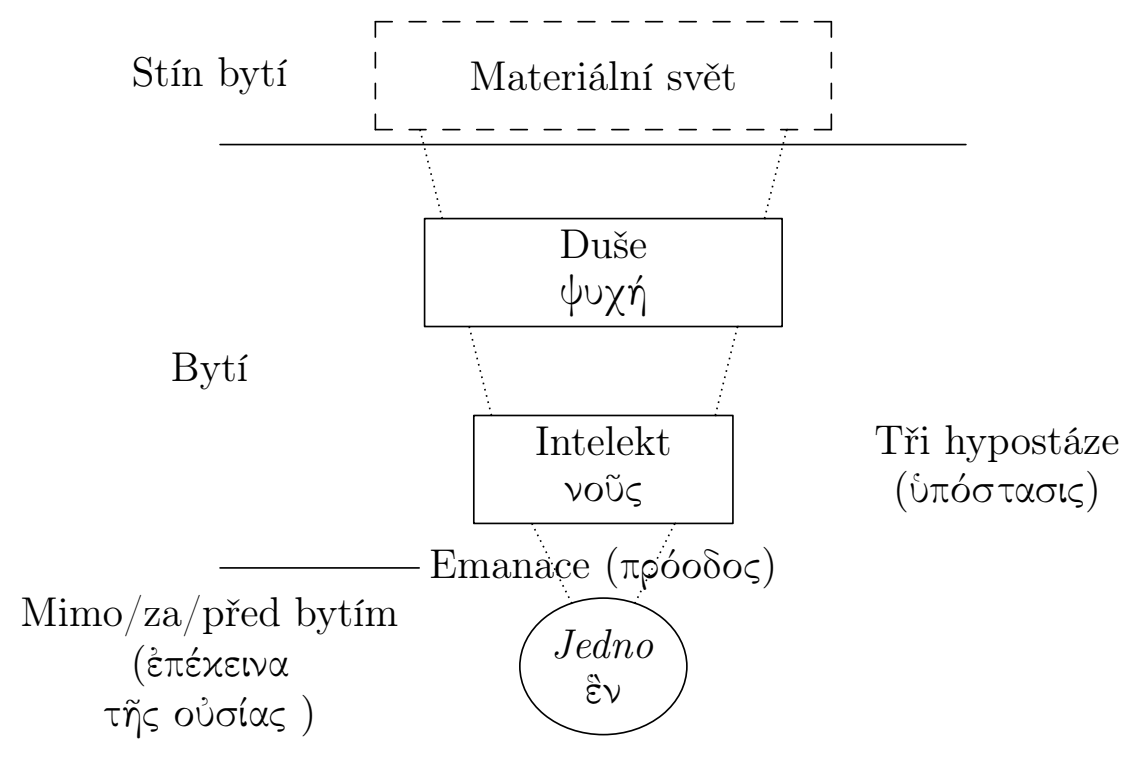

Obrázek 1: Struktura Plótínova metafyzického systému

s Intelektem. Každý další ontologický stupeň je odrazem či obrazem toho vyššího. Podívejme se nyní ve stručnosti na jednotlivé hypostáze.

\section{Jedno}

Výklad Jedna znesnadňuje skutečnost, že podle Plótína je ve své podstatě nevyjádřitelné a nevysvětlitelné. Nelze říci, co Jedno je. ${ }^{1}$ každý výklad je neadekvátní a snaha o jeho zachycení nemůže být nikdy úspěšná. Přesto, jak poznamenává např́iklad Bussanich, o Jednom Plótínos neustále mluví a vyslovuje zcela zásadní ontologická tvrzení. ${ }^{2}$ Nevyslovitelnost Jedna má ovšem svůj důvod - je dána především tím, že Jedno samo je jakožto ontologický základ Intelektu i základem veškerého myšlení, pojmového uchopení skutečnosti, a tedy i řeči. Jakožto předpoklad možnosti myšlení a řeči vůbec není Jedno plně myslitelné a vyslovitelné. ${ }^{3}$

Jedním ze způsobů, jak se o Jednom alespoň nepřímo vyjadřovat, je negativní řeč - tedy říci, co Jedno není. ${ }^{4}$ Ani samotný výraz Jedno nelze chápat jako pozitivní predikát, jeho významem je především zdůraznění negace jakékoli plurality. Proto se také Plótínos pochvalně vyjadřuje o pythágorejcích, kteří nejvyšší božstvo označovali Apollo $\left(\alpha=\right.$ ne, $\pi$ o $\lambda \lambda \dot{\alpha}=$ mnoho). ${ }^{5}$ Tak někteří interpreti chápou jak Jedno, tak i výraz Dobro používaný pro totéž, jako negativní vymezení. ${ }^{6}$

K Jednu navíc nelze adekvátně přistupovat diskurzivním myšlením. Vhodným způsobem, kterým lze alespoň v určitých aspektech Jedno nahlédnout, je bezpro-

\footnotetext{
${ }^{1}$ Enn., s. V.3.13.7, 14.1.

${ }^{2}$ John Bussanich. "Plotinus's metaphysics of the One". In: The Cambridge Companion to Plotinus. Ed. Lloyd P. Gerson. Cambridge: Cambridge University Press, 1996, s. 38.

${ }^{3}$ Enn., s. VI.6.13.44, VI.9.4.1.

${ }^{4}$ Enn., s. V.3.14.6.

${ }^{5}$ Enn., s. V.5.6.26.

${ }^{6}$ Enn., s. VI.6.13.44, VI.9.4.1; Wallis, op. cit., s. 59.
} 


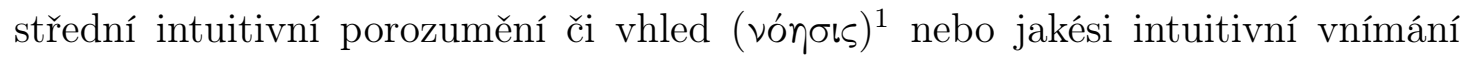

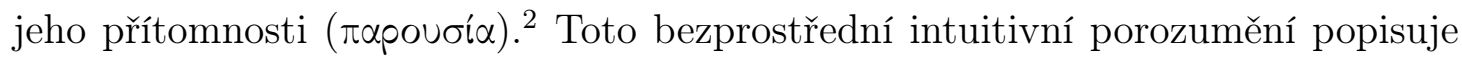
Bussanich následovně: ${ }^{3} 1$ ) toto porozumění nepřipouští omyl: ${ }^{4}$ 2) je věčně vě-

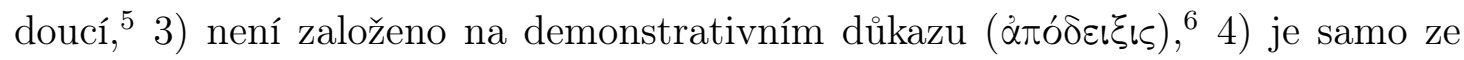
sebe evidentní, ${ }^{7} 5$ ) není třeba po něm pátrat, ${ }^{8}$ 6) není získáno rozumovou úvahou

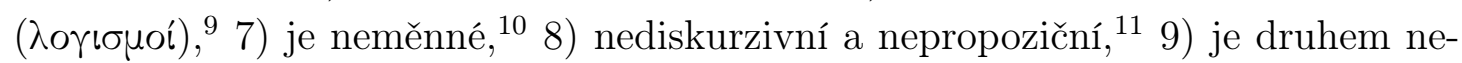
vědění, $\left.{ }^{12} 10\right)$ je vyzařující a transparentní. ${ }^{13}$ Takové poznání má pak zjevně spíše podobu mystické vize než rozumového vědění v běžném slova smyslu. Neznamená to ovšem, že by Plótínos byl iracionalistou a odvolával se výhradně na tuto nerozumovou formu poznávání - uvědomme si, že zde je řeč výhradně o Jednom, metafyzickém základu veškerého jsoucna, které stojí mimo bytí i mimo myšlení. Máme-li si k němu získat nějak přístup, pak jiné možnosti než tato mystické vize jsou podle Plótína obtížně myslitelné. ${ }^{14}$

Na cestě k poznávání Jedna nám může pomoci i reflexe toho, co z Jedna vychází, co je jím produkovánc ${ }^{15}$ - jedná se především o poznávání Intelektu, inteligibilního světa, který je v ontologické hierarchii bezprostředním produktem Jedna. Každý produkt je nedokonalým obrazem svého původce, proto i skrze poznávání z Jedna vyšlých produktů můžeme Jedno určitým nedokonalým, předběžným způsobem poznávat. Proto pokud o Jednu mluvíme s použitím přílastků, které nacházíme na nižších ontologických stupních, jež jsou pro použití na této nižší úrovni adekvátní, neříkáme nepravdu, ale v důsledku neadekvátního použití těchto pojmů na vyšší ontologické úrovni si musíme být vědomi jejich pouze analogické či metaforické platnosti. $^{16}$

Poznání Jedna je přitom nejvyšší cíl veškeré filosofie. ${ }^{17}$ Jistota existence Jedna a také Intelektu je od určité úrovně filosofování evidencí, ke které se není třeba dobírat diskurzivním myšlením, ale naopak ji lze pokládat za východisko. Proto také Bussanich označuje Plótína za „mystického empiristu.“18 Poznání Jedna pak

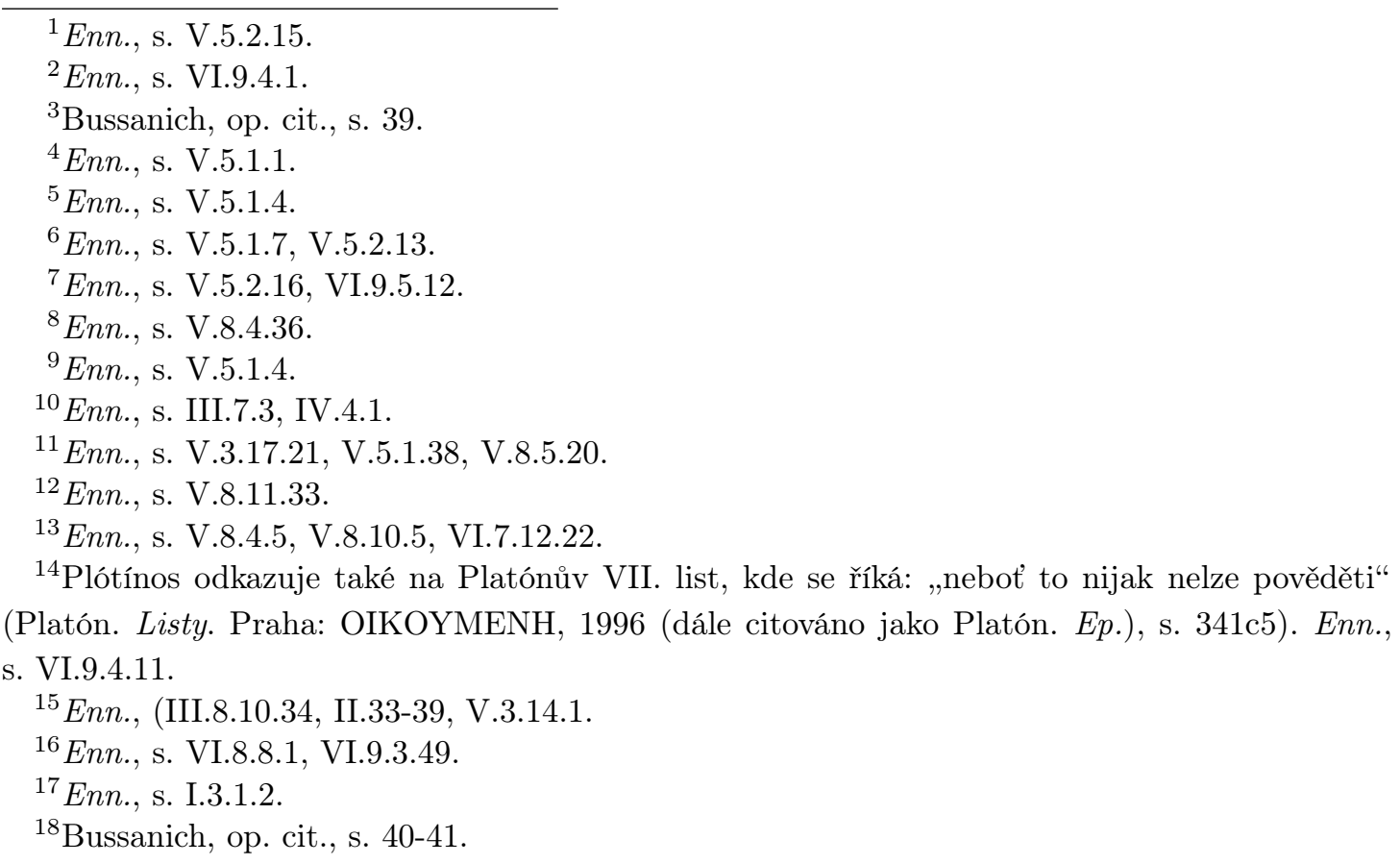


je zároveň sjednocením s ním. ${ }^{1}$

Plótínos také zdưrazňuje, že Jedno není první ve smyslu prvního v pořadí

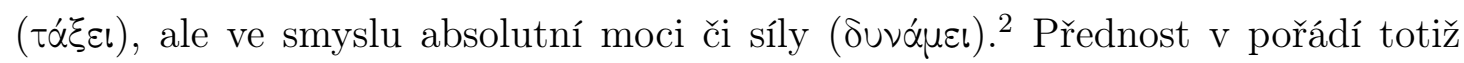
předpokládá určité uspořádání, jehož členy mají cosi společného a odlišují se naopak určitými diferencemi. ${ }^{3}$ Prvotnost Jedna v tomto smyslu určitě chápat nelze. ${ }^{4}$

Jedno také není možné chápat jako nějaký objekt nebo entitu. ${ }^{5}$ Jedno se k ničemu dalšímu nevztahuje, ovšem jiné věci se mohou vztahovat $\mathrm{k}$ Jednu. ${ }^{6}$ Jedno samo je tak nezávislé na čemkoliv jiném, soběstačné, ${ }^{7}$ případně „mimo soběstačnost / za soběstačností“ 8 Jedno je jednoduché, tedy bez částí nebo vnitřních

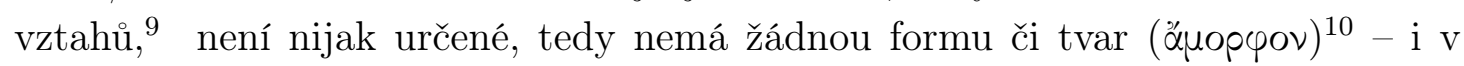
tomto smyslu je „mimo bytí“.

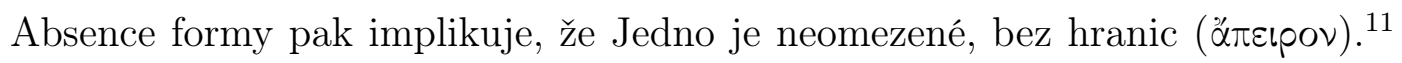

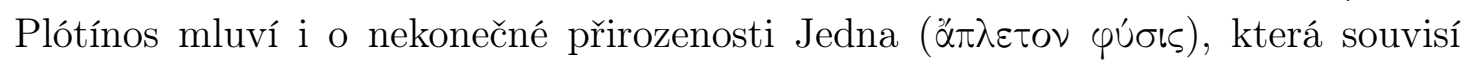

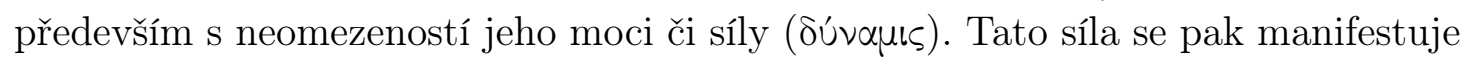
především v produkci Intelektu, druhé hypostáze, tedy inteligibilního světa. ${ }^{12}$

Jedno je dokonalé, což plyne z jeho nezávislosti na čemkoliv jiném a jednoduchosti, jež plyne z jeho vlastní podstaty (lze-li toto slovo použít). ${ }^{13}$ Jeho dokonalost je také spojena s aristotelskou představou plné skutečnosti, aktuality (Ẻvépreı) (v protikladu k pouhé možnosti, potencialitě), Jedno tedy v plné skutečnosti zahrnuje vše. ${ }^{14}$

Analýzu metafyzické povahy Jedna tak můžeme uzavřít pozorováním, že s ohledem na Aristotelovu klasifikaci tříd jsoucen ${ }^{15}$ nespadá Jedno do ani jedné z těchto tříd. Z hlediska této klasifikace stojí mimo všechna jsoucna.

Jedno je Plótínem označováno někdy také jako Dobro, a zakládá tak i oblast

${ }^{1}$ Enn., s. VI.7.36.

${ }^{2}$ Enn., s. VI.8.20.28.

${ }^{3}$ Enn., s. V.5.13.21.

${ }^{4}$ O'Meara, op. cit., s. 77.

${ }^{5}$ Enn., s. II.9.1.1, VI.7.38.4, VI.9.5.29.

${ }^{6}$ Enn., s. VI.8.8.12, VI.9.6.40.

${ }^{7}$ Enn., s. VI.7.32.9.

${ }^{\varepsilon}$ Enn., s. V.3.17.14.

${ }^{9}$ Jedno nemá vnitřních vztahů, vyjma vztahu k sobě samému, jakési vnitřní „,sebevztaženosti“ (Enn., s. VI.8.14.25), kterou ovšem např. Bussanich doporučuje opět chápat nikoli jako vztah nějakých vnitřních komponent Jedna, ale spíše zdưraznění nezávislosti Jedna na čemkoli dalším, způsob zdůraznění absence vztahu k něčemu dalšímu. Podobně nikoli doslovně je třeba chápat tvrzení, že Jedno je př́ičinou sebe sama (Enn., (VI.8.13.55, VI.8.14.41, VI.8.16.14), kterému je lépe rozumět tak, že Jedno nemá žádnou vnější či jinou přičinu mimo sebe sama (Bussanich, op. cit., s. 45).

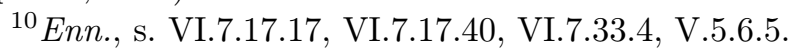

${ }^{11}$ Enn., s. V.5.10.18.

12 Enn., s. V.4.1.23, V.5.10.18, VI.9.6.10, II.4.15.17, VI.9.6.7, V.5.11.1.

${ }^{13}$ Enn., s. V.1.6.38, V.6.2.13.

${ }^{14}$ Enn., s. VI.8.20.9. Toto všezahrnování navazuje na Aristotelovo pojetí dokonalosti - „... to pak, mimo co nic není, jest úplné a celistvé, nebot tak definujeme celek (ő̀ov), totiž jako to, čemu nic neschází,... celek jest to, vně čeho nic není... " (Aristotelés. Fyzika. Překl. A. Kříž. Praha: Nakladatelství Petr Rezek, 1996 (dále citováno jako Phys.), 207a9). Srv. Bussanich, op. cit., s. 44.

${ }^{15}$ Vacura, op. cit., s. 3. 
etiky. Jedno je tedy nejen základním počátkem všeho bytí (ápxপ́), ale zároveň

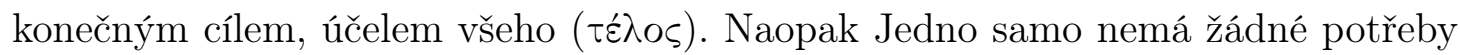
či touhy, je zcela prosté jakékoli žádosti, ${ }^{1}$ proto je také dobré pouze pro druhé, nikoli pro sebe sama. ${ }^{2}$ Plótínos jde ovšem na některých místech ještě dále - Jedno není pouze soběstačné, ale je ,za“ soběstačností, a tedy „za“ Dobrem. ${ }^{3}$ Samo Jedno je tedy konečným dobrem a cílem - je si žádáno proto, že je dobrem, je tedy objektivním dobrem (nikoli, že by bylo dobré proto, že by bylo žádáno). ${ }^{4}$ Tato jeho charakteristika jako konečného účelu podle Plótína souvisí s absencí jakékoli formy či konkrétní kvality Jednu připsatelné. ${ }^{5}$ Wallis upozorňuje na paradoxní podobnost Jedna na jedné straně a beztvaré hmoty na straně druhé - obojí stojící na protikladných pólech Plótínovy ontologické hierarchie. ${ }^{6}$

Jedno je takové, jaké je, nutně, ${ }^{7}$ což ovšem neomezuje v Plótínově pojetí jeho absolutní svobodu.

\section{Jedno a produkce dalších úrovní skutečnosti - emanace}

V úvodu jsme již ukázali, že Plótínova metafyzická koncepce zahrnuje hierarchické uspořádání skutečnosti, v jehož základu stojí Jedno. Jaký je však vztah mezi Jednem a ostatními stupni bytí? Viděli jsme, že Jedno nemá žádné vnější vztahy k čemukoli dalšímu, je zcela nezávislé, soběstačné a vůbec mimo bytí a jsoucno. Pokud používáme pojmy jako princip, příčina apod. k popisu vztahu Jedna k ostatním stupňům bytí, musíme si být vědomi, jak už bylo zdůrazněno, že takové použití pojmů primárně vhodných pro nižší stupně skutečnosti je jen analogické či metaforické, umožňuje nám se jen v náznaku přiblí̌zit povaze vztahu Jedna a všeho ostatního, ovšem tyto pojmy nemohou nikdy plně vyjádřit jeho skutečnou podstatu.

Jedno je k ostatnímu ve dvojí pozici. Za prvé je Jedno přičinou či předchůdcem

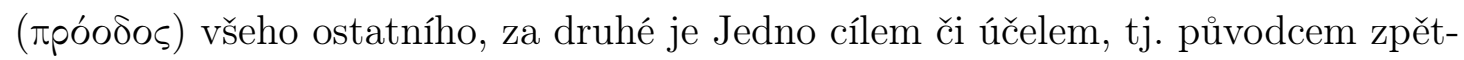
ného ,pohybu“ či návratu ( aktivity přitom vysvětluje existenci a vznik světa (jak inteligibilního, tak v dalším řádu i materiálního), druhá aktivita je základem smysluplnosti světa a v důsledku i etiky.

Jednotné Jedno je tak „předchůdcem“ či přičinou všeho, co je nejednotné, složené, komplexní, atd. ${ }^{8}$ Jak ale může jednota dát vzniknout mnohosti? Plótínos

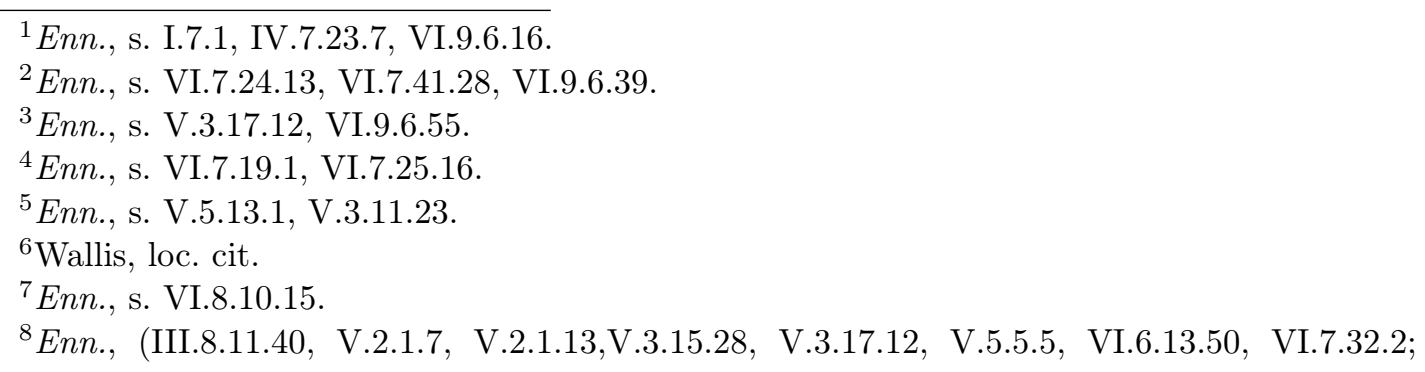


Intelekt, Duše, materiální svět

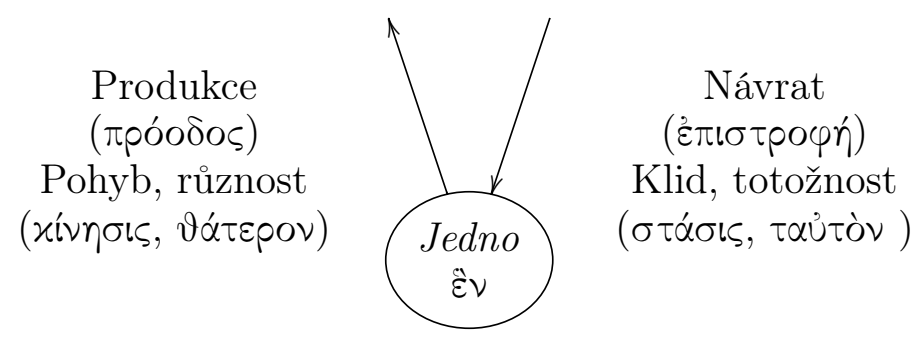

Obrázek 2: „Produkce“ a „návrat“ v Plótínově metafyzickém systému.

tvrdí, že produkt je vždy méně dokonalý než producent (předchůdce), proto je-li v tomto případě předchůdcem plně jednotné Jedno, produkt musí být méně dokonalý, tedy nejednotný. Produkt musí tedy obsahovat určitou pluralitu, mnohost. ${ }^{1}$ Tímto produktem je v první řadě Intelekt, inteligibilní svět mnohosti ideálních forem. Naopak ovšem Jedno musí v nějaké podobě obsahovat sjednocenou mnohost Intelektu (i dalších odvozených stupňů skutečnosti). ${ }^{2}$ Wallis upozorňuje, že v rámci Plótínova systému jsou takové předpoklady plně konzistentní, nebot’ z platónského pohledu lze poukázat na to, že ač mnohost je vždy nejednotná pluralita, přesto forma či idea mnohosti je sama jednotou. ${ }^{3}$ Analogicky (ale jen pouze analogicky!) lze myslet vztah mezi Intelektem a Jednem. Ač v sobě tedy Jedno vše nějak zahrnuje, přesto není samo žádnou věci ${ }^{4}$ ani není jejich prostým souhrnem. ${ }^{5}$

Pokud se vrátíme k otázce produkce ostatních stupňů reality z Jedna, Plótínos pro vysvětlení používá řadu metafor, například vyzařování tepla z ohně, chladu ze sněhu či světla ze slunce. ${ }^{6}$ Termín emanace, který je odvozen od výrazu používaného mj. právě pro tok světla ze slunce (lat. emanare - vytékat, vyvěrat), se často používá pro vyjádření charakteru této produktivnosti Jedna. Wallis upozorňuje, že všechna tato přirovnání musíme opět chápat jen metaforicky, zejména proto, že například slunce je prostorově lokalizované a stejně tak světelný tok má určité prostorové (a případně časové) charakteristiky, od kterých musíme abstrahovat. Zároveň je důležité si uvědomit, že Plótínos považuje světlo ve smyslovém světě za nemateriální sílu, nikoli jako stoikové za sílu materiální nebo jako Aristotelés za akcidentální modifikaci vzduchu. ${ }^{7}$

Základem prvního stupně emanace, tedy produkce Intelektu z Jedna, je tolma

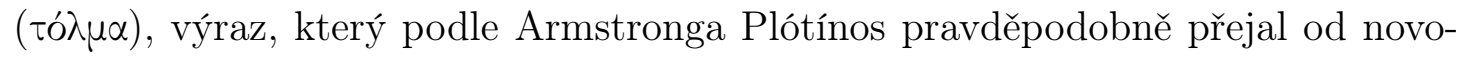
pythágorejců, kteří tímto slovem nazývali dvojici, „protože byla tím prvním, co se oddělilo od monády". ${ }^{8}$ Jedná se o jakýsi neurčitý princip mnohosti, nezformo-

VI.8.19.12.

${ }^{1}$ Enn., s. V.3.15.1, VI.7.8.17.

${ }^{2}$ Enn., s. V.2.1.2, VI.8.18.32.

${ }^{3}$ Srv. Enn., s. II.4.9.5, III.6.17-18; Wallis, op. cit., s. 20, 49, 60.

${ }^{4}$ Enn., s. V.2.1.1, VI.7.32.12.

${ }^{5}$ Enn., s. III.8.9.39, V.5.13.17.

${ }^{6}$ Enn., s. V.1.6.28, V.3.12.39, V.4.1.23.

${ }^{7}$ Wallis, op. cit., s. 61. Srv. Enn., s. IV.5.6, II.1.7.26, I.1.4.12, IV.3.22.1.

${ }^{8}$ Arthur Hilary Armstrong. "Plótínos". In: ed. A. H. Armstrong. Praha: OIKOYMENH, 2002, 
vanou touhu po oddělené existenci, touhu „být jako taková“, tedy o touhu politováníhodnou, protože se jedná o touhu po čemsi menším, než je Dobro. ${ }^{1}$ Tato prvotní podoba tendence k různosti se pak manifestuje i na jiných úrovních skutečnosti různým způsobem, např. v případě duše se jedná o vnitřní neklid, touhu po neustálé aktivitě, po pohybu pro něj samý, po neustávajícím sledu po sobě následujících událostí či prožitků. ${ }^{2}$

Podstatnou charakteristikou emanace, stejně jako každé další produkce nižších stupňů skutečnosti z vyšších, je, že touto produkcí nedochází k úbytku či umenšení producenta ani jeho vnitřní síly či energie. ${ }^{3}$ Zároveň je produkováno vše, co vůbec lze vyprodukovat, na každém z nižších stupňů dochází k jakési dokonalé aktualizaci, uskutečnění všeho, co je vůbec možné. Nic nezůstává neuskutečněno, v pouhé možnosti. Přestože tedy Plótínos na jednom místě říká, že by Jedno mohlo vyprodukovat nějaký další vesmír, ihned tuto myšlenku odmítá, protože není možné, aby něco takového bylo vyprodukováno, jakmile Všechno existuje. ${ }^{4}$ Emanativní produkce tedy vytváří na každé úrovni skutečnosti plnost existence - poté, co je tato plnost skutečná, sestupuje produktivní síla na další, nižší úroveň skutečnosti a tu opět plně vyprodukuje. Každý další stupeň je nedokonalejší, neurčenější, je jen odrazem stupně předchozího. Produkce je ukončena na úrovni temné, beztvaré matérie, která nemá žádné charakteristiky. ${ }^{5}$ Tak je vyprodukováno Vše, co vůbec může existovat. Vidíme, že výraz Vše nemá pouze deskriptivní význam souhrnu nahodile existujícího, ale jeho význam je silnější - nic dalšího než to, co již existuje, už existovat nemůže. Vše, co vůbec může být jsoucím, jest a je součástí plné skutečnosti Všeho, které Jedno vyprodukovalo a co vůbec vyprodukováno být mohlo. Tak jsou skutečnost a možnost na této úrovni sjednoceny. ${ }^{6}$

Je zřejmé, že je-li vyprodukováno Vše, co vůbec může být skutečné, pak přrinejmenším na úrovni smyslového světa existují bytosti a věci různě přiměřené svým inteligibilním vzorům či vůbec různě dobré, tedy odrážející v sobě v různé míře Dobro jako takové. ${ }^{7}$ Produkováno Jednem je dokonce i to, co chápeme jako zlé. Přesto však Plótínos podržuje představu celku Všeho jakožto dokonalého a uvádí metaforu malby, která nemusí mít krásné barvy na každém místě, přesto jako celek může být malířem vytvořena jako krásná. ${ }^{8}$ Tato metafora, která, pokud víme, má původ právě u Plótína, byla v dějinách filosofie nesmírně vlivná.

Samotné vysvětlení emanace Jedna jako takové vychází z pozorování (re)pro-

s. 280 .

${ }^{1}$ Ibid., s. 280.

${ }^{2}$ Ibid., s. 289.

${ }^{3}$ Enn., s. III.8.8.46, III.8.10.1.

${ }^{4}$ Enn., s. V.5.12.40.

${ }^{5}$ Enn., s. IV.8.6, V.2.2.1.

${ }^{6}$ Tento závěr může působit paradoxně, ale už Platón v Timaiovi říká, že vesmír by byl neúplný, pokud by neobsahoval všechny možné žijící tvory (Platón. Timaios. Praha: OIKOYMENH, 2008 (2014) (dále citováno jako Tim.), 30c, 39e). Historickým rozborem této myšlenky, která je nazývána princip mnohosti a souvisí s tzv. velkým řetězcem bytí, se zabývá Arthur O. Lovejoy. The Great Chain of Being. Harvard University Press, 1936.

${ }^{7}$ Enn., s. II.9.13.1, II.9.13.25, III.2.14.6, III.3.3.

${ }^{\varepsilon}$ Enn., s. III.2.11. 
dukování na nižších úrovních reality. Dokonalé Jedno „př̌etéká“ svou mocí či sílou, výsledkem čehož je emanativní produkce. ${ }^{1}$ Wallis dává tento princip do souvislosti s klasickým principem předávaným různými filosofickými tradicemi, jenž je vyjádřen v scholastickém mottu ,dobro se šřři““ (bonum diffusivum sui). ${ }^{2}$ Neboli dokonalé entity si nepodržují svou dokonalost jen pro sebe, ale šíři ji, a vytvářejí tak vnější obraz svého vnitřního dokonalého stavu. Podobně pak můžeme chápat metafyzickou příčinu emanace z Jedna. ${ }^{3}$ Aby takový charakter Jedna Plótínos osvětlil, používá ve vztahu k němu někdy výraz $\alpha \varphi \vartheta o v i ́ \alpha$, který lze přeložit jako naprostou absenci sobectví či závisti. ${ }^{4}$

Dalším podobným východiskem zdůvodnění emanace je analýza kontemplativního stavu, který Plótínos připisuje jsoucnům na různých ontologických úrovních - kontemplace jsou schopny individuální duše, ve „spící kontemplaci“ se nachází světová duše jakožto příroda: ${ }^{5}$ stejně tak na úrovni Intelektu jsou, jak uvidíme dále, kontemplujícími jednotlivá inteligibilní jsoucna i Intelekt sám jako hypostáze, jako božský rozum. Tato kontemplace, zaměření do sebe, vnitřní „aktivita“, je pro Plótína na každé ontologické úrovni zdrojem vnitřní energie a síly. ${ }^{6}$ Vnější produkce, kreativní síla, je pak na každé úrovni důsledkem nadbytku této vnitřní energie. Tak i Jedno můžeme podle Wallise chápat jako nacházející se ve stavu jakési „hyper-kontemplace“, která je příčinou nadbytku vnitřní energie, což vede k emanativní produkci dalších stupňů reality. ${ }^{7}$ Je však tř̌eba zdưraznit, že tato produkce se neděje podle nějakého úvahy, záměru nebo plánu. ${ }^{8}$ ale je zcela spontánní, ${ }^{9}$ ovšem bez jakékoli touhy, vủle, pohybu či změny. ${ }^{10}$ Odehrává se také mimo časová určení, nejedná se tedy o proces, který by měl počátek a průběh, spíše se tímto výrazem snažíme zachytit vztah závislosti a odvozenosti. ${ }^{11}$

Tyto charakteristiky produkce nižších úrovní skutečnosti pak platí nejen pro Jedno, ale i pro produkce na dalších stupních ontologické hierarchie, tedy pro produkci Duše z Intelektu a smyslového světa z Duše. Každý stupeň této produkce je spontánní a bez jakéhokoli záměru, tedy nelze tuto produktivní činnost přirovnávat k práci lidského řemeslníka. ${ }^{12}$ Platónově analogii v dialogu Timaios je tedy

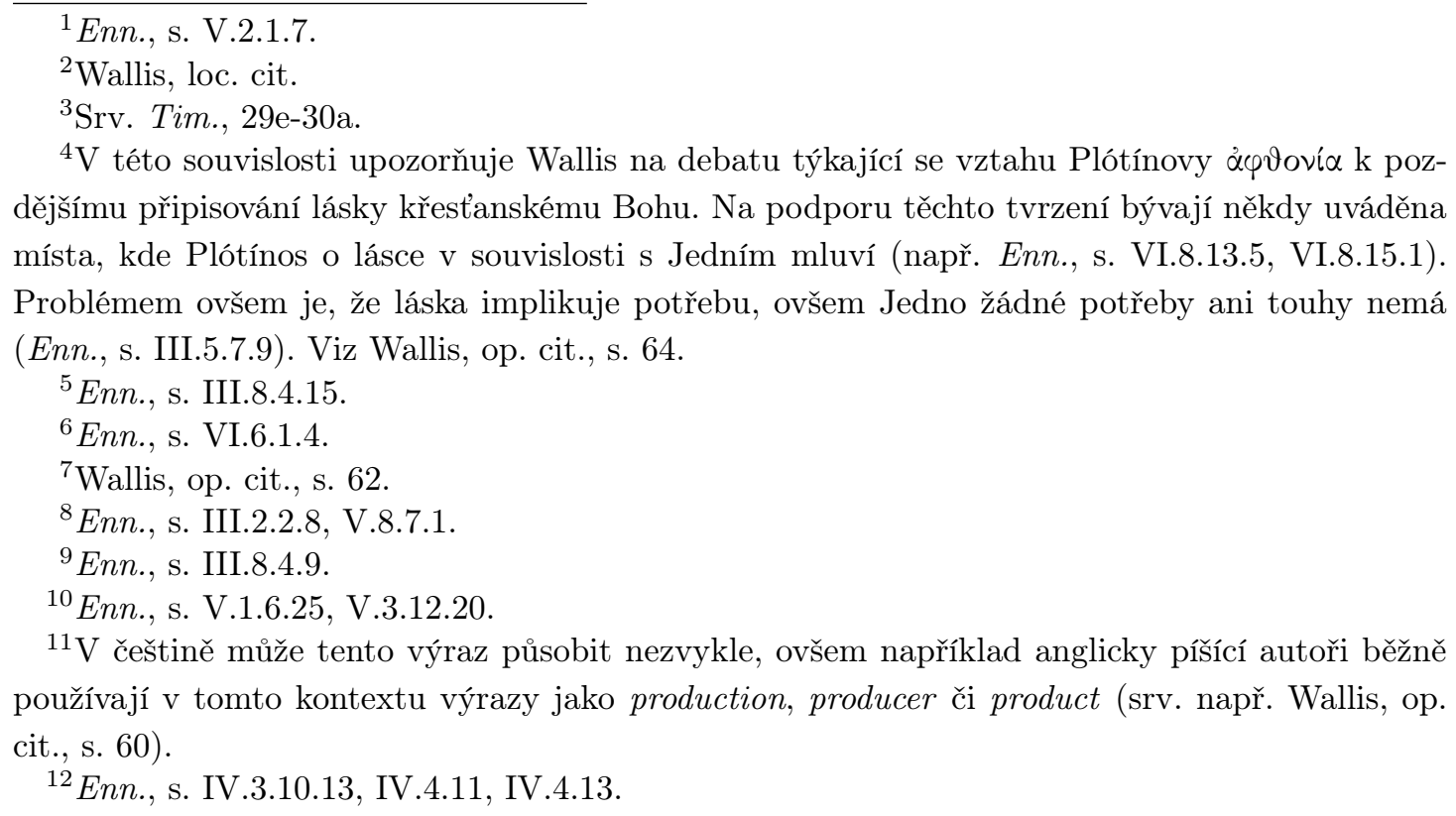


nutno rozumět v tom smyslu, že svět je tak dobrý, jako by byl vytvořen na základě nejlepší možné úvahy. ${ }^{1}$

\section{Intelekt}

$\mathrm{V}$ řadě charakteristik je Intelekt blízký tomu, co už jsme zmínili v souvislosti s Jednem. ${ }^{2}$ Intelekt je dokonalý; ${ }^{3}$ žije dokonalým životem, ${ }^{4}$ je plně skutečný; ${ }^{5}$ soběstačný ${ }^{6}$ a také disponuje nekonečnou mocí či silou. ${ }^{7}$ Naopak na rozdíl od Jedna není Intelekt jednotný, je svou povahou mnohostí, rozlišeností a určeností.

Na druhé straně je Intelekt v některých ohledech blízký Duši a Plótínos na některých místech používá výraz voũs pro obojí. Rozlišení mezi Intelektem a Duší Plótínos často vykládá na základě způsobu přístupu - zatímco inteligibilní svět Intelektu je předmětem myšlení ve formě vónoıs, tj. bezprostředního intelektuálního nazírání idejí, které nemá časově strukturovaný průběh, tak myšlení na úrovni Duše má v čase strukturovaný, diskurzivní charakter. ${ }^{8}$ Tento rozdíl je přirozeně dán tím, že Intelekt, jakožto hypostáze, je věčný nebo bezčasový. Čas vstupuje do Plótínova ontologického systému až na úrovni Duše, která je časová, ač jakožto hypostáze existuje vždy (viz tabulka 1 na str. 21 ) ${ }^{9}$

Intelekt jakožto inteligibilní svět sestává z idejí či forem, at’ už jako druhů na různých úrovních obecnosti, či idejí matematických (Plótínos o nich mluví jako o prvních $^{10}$ nebo pravých jsoucnech $\left.{ }^{11}\right)$. Tyto jednotlivé ideje jsou však pro Plótína individuálními živými, myslícími bytostmi (ač myslícími v mimočasovém slova smyslu), které zároveň samy, jakožto ideje, mohou být předmětem myšlení - a jsou tedy předmětem myšlení nejen lidského, ale především myšlení Intelektu samého. Podstata Intelektu je pak shodná s podstatou jím myšlených obsahů: „Nebot’ kdyby jeho podstata byla jiná než jeho myšlení a věci, které myslí, by se od něho odlišovaly, pak by podstata věcí, které myslí, byla nepřístupná myšlení; a opět by byl Intelektem pouze v možnosti, a nikoliv ve skutečnosti. “12 Tím je zajištěn Intelekt, ve kterém je myšlení identické s předmětem myšlení - tedy Intelekt jak co se týče svých částí, jednotlivých idejí, tak jako celek myslící sebe sama: „Jestliže Intelekt myslí ze sebe samého a skrze sebe samého, pak on sám je tím, co je myšleno."13 Takový Intelekt je božským rozumem, podobný sebe sama myslícímu

\footnotetext{
${ }^{1}$ Enn., s. III.2.14.1, VI.2.21.32, VI.7.1.28, VI.8.17.1. Srv. Wallis, op. cit., s. 63.

${ }^{2}$ Bussanich, loc. cit.

${ }^{3}$ Enn., s. III.6.6.10-17, V.1.4.1.

${ }^{4}$ Enn., s. V.3.16.29, V.1.10.12.

${ }^{5}$ Enn., s. II.5.3.31, VI.2.20.

${ }^{6}$ Enn., s. V.3.13.1.

${ }^{7}$ Enn., s. V.7.1, VI.5.12, VI.6.18.

${ }^{\varepsilon}$ Enn., s. III.7.11.20; srv. Platón. Ústava. Praha: OIKOYMENH, 2005 (dále citováno jako Rep.), s. 511d.

${ }^{\mathrm{g}}$ Enn., s. III.7.11.23.

${ }^{1 C}$ Enn., s. V.9.5.18.

${ }^{11}$ Enn., s. V.9.5.18.

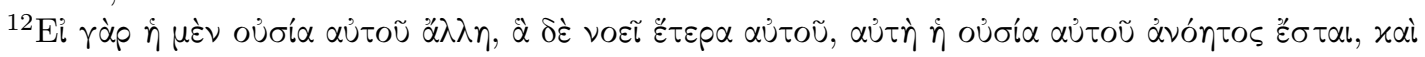

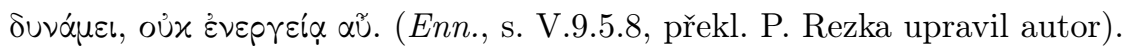

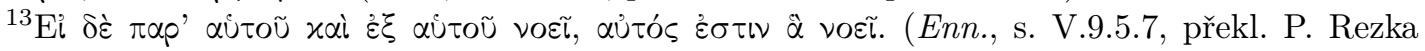




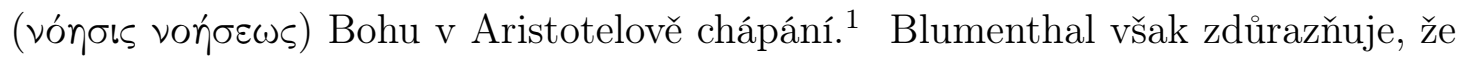
zatímco v Aristotelově pojetí božský rozum myslí skutečně jen své vlastní myšlení bez nějakého konkrétního obsahu, v Plótínově případě Intelekt myslí své vlastní ideové obsahy. ${ }^{2}$ Tyto ideové obsahy svým myšlením činí skutečnými, jsoucími, a zároveň jest skrze své myšlení jimi samými: „Je jasné, že Intelekt, protože je opravdu jsoucí, jsoucna myslí a propůjčuje jim bytí. Je tedy oněmi jsoucny. “3 Plótínos také v tomto smyslu souhlasně cituje Parmenida, Aristotela, Hérakleita a Platóna: ${ }^{4}$

Bylo tedy správně řečeno, že ,,jedno a totéž je myšlení a bytí“5 a ,věda o nelátkových věcech je totožná se svým oborem“6 a „prozkoumal jsem sebe sama“7 jako jedno ze jsoucen; a správná je nauka o anamnézi.

Sféra Intelektu tak není jako Aristotelův božský rozum jakousi nerozlišitelnou homogenitou, ale je naopak bytostnou mnohostí, jasně rozlišenou růzností nejen navzájem od sebe odlišených idejí, forem, ale i různých individuálně myslících intelektů. Intelekt je tak mnohostí objektů a subjektů, které však, to je třeba zdůraznit, spočívají v bezčasé věčnosti, v myšlení, které má charakter věčné kontemplace. Tyto ideje, první věci, které jsou obsahem Intelektu, však nejsou nikde lokalizovány, nenacházejí se na nějakém místě; Intelekt, stejně jako svět idejí, není někde vedle, mimo nebo za smyslovým světem, v místním smyslu. Plótínos říká: „Žádné z pravých jsoucen není někde mimo ( nýbrž všechna setrvávají věčně v sobě samých a nepodléhají změně ani zániku. "8 Právě to, že jsou mimo čas, a tedy mimo změnu a možnost vzniku a zániku, činí tyto ideje skutečnými, prvními jsoucny: „Kdyby vznikala a zanikala, potřebovala by, aby se k nim jsoucnost < teprve> připojila, a tedy nikoliv ona jsoucna, nýbrž ono připojené by bylo pravým jsoucnem. "9

Je to zároveň právě sféra Intelektu, která, podobně jako Platónova říše idejí, poskytuje věčné vzory pro vše, co se nalézá na nižších metafyzických úrovních. Smyslové věci získávají svou určitost právě na základě participace na věčných vzorech: „Věci přístupné smyslům jsou tím, čím jsou nazývány, na základě účasti; přirozenost, která je pro ně podkladem určení, svůj tvar přijímá odjinud... "10

upravil autor).

${ }^{1}$ Srv. Aristotelés. $O$ duši. Překl. A. Kř́̌ž. Praha: Nakladatelství Petr Rezek, 2000 (dále citováno jako De An.), 431a1; Aristotelés. Metafyzika. Překl. A. Kř́žz. Praha: Nakladatelství Petr Rezek, 2003 (dále citováno jako Met.), 1074b15.

${ }^{2}$ Henry J. Blumenthal. "On soul and intellect". In: The Cambridge Companion to Plotinus. Ed. Lloyd P. Gerson. Cambridge: Cambridge University Press, 1996, s. 94.

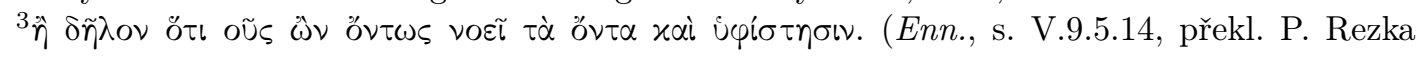
upravil autor).

${ }^{4}$ Enn., s. V.9.5.8, překl. P. Rezka upravil autor.

${ }^{5}$ Parm. $z l$. B 3.

${ }^{6}$ De An., 431a1.

${ }^{7}$ Hérakl. zl. B 101.

${ }^{8}$ Enn., s. V.9.5.33.

${ }^{9}$ Enn., s. V.9.5.35.

${ }^{1 C}$ Enn., s. V.9.5.37. 
Specifickou roli na metafyzické úrovni Intelektu hraje tzv. inteligibilní látka, která představuje jakousi předlohu smyslové látky na úrovni smyslového světa. ${ }^{1} \mathrm{Na}$ rozdíl od smyslové látky však inteligibilní látka nemá její nedostatky, není ,zlem“. ${ }^{2}$ Wallis ${ }^{3}$ upozorňuje, že přestože výraz „inteligibilní látka“ najdeme i u Aristotela. ${ }^{4}$ ten jej používá v jiném smyslu. Bližší souvislost pak vidí s Platónovou koncepcí neurčité dvojice, která tvoří součást Platónových nepsaných nauk a je chápána jako základ teorie idejí. ${ }^{5}$

Dalším pojmem souvisejícím s Intelektem jako hypostází je život. Podle Wallise Plótínos k tomuto tématu na různých místech uvádí tvrzení, která lze jen obtížně uvést v soulad. ${ }^{6}$ Život někde prezentuje jako přechod mezi Intelektem a Duší, jinde jej chápe jako druhou hypostázi v bezforemném stavu, tedy jako stav produkce této hypostáze Jednem, zatímco Intelekt pak pojímá jako druhou hypostázi, když byla již vnitřně vymezena a zformována. ${ }^{8}$

\section{Duše}

Pokud mluvíme u Plótína o duši, musíme rozlišovat mezi individuální duší jednotlivého člověka a světovou duší. Zároveň ovšem musíme tyto významy odlišit od případů, kdy Plótínos mluví na metafyzické úrovni o Duši jakožto hypostázi. Plótínos píše na různých místech o duši v těchto třech významech různým způsobem, ačkoli je zřejmé, že jsou vnitřně propojeny, každý z těchto významů pojmu duše se pojí s jinými určeními. Vzájemnému vztahu těchto různých podob duše a jejich jednotě se Plótínos věnuje především v Enneadách IV.9 a IV.3.

Jak z lokalizace Duše v rámci Plótínova metafyzického systému vyplývá, má styčné plochy na jedné straně s Intelektem, na druhé straně s materiálním smyslovým světem. V obou těchto styčných bodech dochází k jistému úzkému propojení, ovšem zároveň se Plótínos snaží udržet jasné oddělení jednotlivých hierarchických metafyzických rovin.

\section{Světová duše}

V nižší rovině tak dochází k tomu, že na jedné straně světová duše produkuje formu světa, dává materiálnímu světu jeho tvar a obsah, ${ }^{9}$ na druhé straně pak individuální lidská duše vstupuje do lidského těla jako oživující, oduševňující prvek. Světová duše tím, že dává tvar a obsah materiálnímu světu, transformuje látku bez formy

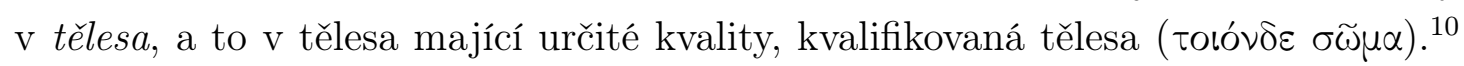

\footnotetext{
${ }^{1}$ Enn., s. II.4.5.24, III.8.11.1.

${ }^{2}$ Enn., s. II.4.5.12, II.4.15.17, II.5.3.8.

${ }^{3}$ Wallis, op. cit., s. 66.

${ }^{4}$ Met., 1036a9, 1037a4, 1045a34.

${ }^{5}$ Enn., s. V.1.5.6, V.4.2.7.

${ }^{6}$ Wallis, op. cit., s. 67.

${ }^{7}$ Enn., s. VI.6.8.17, VI.6.17.35.

${ }^{\varepsilon}$ Enn., s. VI.7.17.14, VI.7.21.2.

${ }^{\mathrm{Q}}$ Enn., s. II.1.5.6.

${ }^{1 \mathrm{C} E n n ., ~ s . ~ I V .4 .18 . ~}$
} 


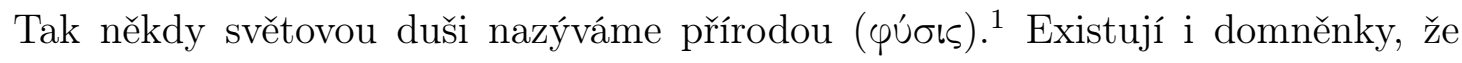
přírodu či nejnižší části Duše by bylo možné chápat jako čtvrtou hypostázi, ovšem ty nejsou obvykle považovány za dostatečně podložené. ${ }^{2}$

Světová duše tedy není složena z individuálních duší, ty nejsou ani jejími částmi, jak si představovali stoikové. ${ }^{3}$ Světová duše, ač ji můžeme chápat jako (neosobní) přírodu, je přesto sama také individuální duší. To pak vede k představě, že jak světová, tak individuální duše, jsou manifestací jediné univerzální duše, jejich vzoru na vyšší ontologické úrovni, úrovni Intelektu. ${ }^{4}$

\section{Individuální duše}

Pokud naši pozornost obrátíme nyní k jednotlivé duši, narážíme v Plótínově filosofii zejména na ten problém, že podle jeho pojetí jedna a tatáž individuální duše existuje v mnoha tělech. ${ }^{5}$ Blumenthal však upozorňuje na to, že přes Plótínovu snahu podat uspokojivý výklad této teze obtížně vysvětlíme různost jednotlivých individuálních osob. ${ }^{6}$ Vysvětlení individuální různosti na základě působení matérie je neuspokojivé, protože ta sama žádné individualizující charakteristiky nemá. ${ }^{7}$ Vysvětlení pomocí individuálních forem je potom nejisté, protože není zřejmé, zdali Plótínos koncepci individuálních forem přijímal. ${ }^{8}$

Způsob, jak je lidská duše v lidském těle, přirovnává Plótínos k přítomnosti světla ve vzduchu ${ }^{9}$ případně tepla ve vzduchu. ${ }^{10} \mathrm{~V}$ dělení duše na části někde využívá platónské rozlišení na tři části. ${ }^{11}$ ovšem Blumenthal upozorňuje, že na jiných místech toto rozdělení kritizuje jako nedostatečné. ${ }^{12}$ Plótínos dochází k tomu, že dvě nižší části duše neposkytují dostatečný prostor pro vysvětlení zlosti, vyšších emocí ani žádostí. ${ }^{13}$ Ty je třeba vysvětlit nikoliv s použitím platónského dělení na tři části duše, ale, podobně jako činí Aristotelés, s použitím chtění (őpełıs), která jde napříč tímto dělením a manifestuje se různými způsoby. Na jiných mís-

\footnotetext{
${ }^{1}$ Enn., s. VI.4.15.8.

${ }^{2}$ Enn., s. V.2.1.26. Srv. Henry J. Blumenthal. Soul and Intelect. Studies in Plotinus and Later Neoplatonism. Aldershot: Variorum, 1993, s. 11. Srovnání s Aristotelovým pojetím př́rody (Enn., s. III.8.2, IV.4.12, V.2.1.18).

${ }^{3}$ Enn., s. IV.3.2-3.

${ }^{4}$ Enn., s. IV.3.2.1, IV.3.2.54, IV.3.4.14.

${ }^{5}$ Této diskusi je věnována zejména Enneada V.9 („Zda jsou všechny duše jednou duší“), která vyšla v českém překladu ve sborníku Plótínos. Sestry duše. Praha: Nakladatelství Petr Rezek, 1995.

${ }^{6}$ Blumenthal, "On soul and intellect", s. 85.

${ }^{7}$ Takové je podle některých interpretů i vysvětlení Aristotelovo (Viz diskuse v Terence H. Irwin. Aristotle's First Principles. Oxford: Clarendon Press, 1988, s. 248-268; Anthony C. Lloyd. Form and Universal in Aristotle. ARCA: Classical and Medieval Texts, Papers and Monographs 4. Liverpool: Francis Cairns, 1981, s. 1-48; český překlad druhého z textů byl vydán ve sborníku Petr Rezek, ed. Jednotliviny a individuální formy. Praha: OIKOYMENH, 1993).

${ }^{8}$ Viz poznámka 8 na straně 19

${ }^{\mathrm{Q}}$ Enn., s. IV.3.22.1.

1C Enn., s. IV.4.29.

${ }^{11}$ Enn., s. I.2.1.17.

${ }^{12}$ Blumenthal, op. cit., s. 87.

${ }^{13}$ Enn., s. IV.4.28.1.
} 
tech pak Plótínos použivá i aristotelské dělení na vegetativní ( $\varphi$ tıxóv) část duše, střední část duše disponující vnímáním a na vyšší mohutnosti duše, tj. obrazotvornost ( $\varphi$ $\nu \tau \alpha \sigma i \alpha)$ a rozumové schopnosti. Smyslové vnímání zahrnuje pro Plótína jak

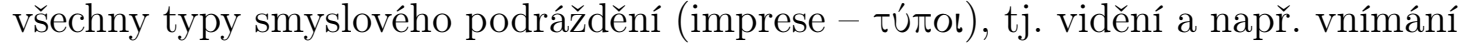
teploty, tak i různé vnitřní tělesné pocity ${ }^{1}$ a je směřováno vždy k materiálnímu světu, tedy vyžaduje i materiální smyslové orgány. ${ }^{2}$

Duše pak není místně lokalizovatelná, lokalizovatelné jsou pouze jí podmíněné aktivity v těle. ${ }^{3}$ Individuální lidská duše „vstupuje“ do těla/tělesa, které je přírodně formováno, má určitý tvar a další kvality a charakteristiky. Stejně tak po smrti individuálního člověka mrtvé tělo již nemá lidskou duši, přesto však má určitý tvar a další kvality, je to kvalifikované těleso. Živý člověk tak jedné straně má vlastní individuální duši, ovšem i jeho tělo není zcela bezduchou matérií, ale je formováno prř́rodou, světovou duší. Individuální duše člověka pak není homogenní, a ačkoli není zřejmé, jaké přesně dělení duše Plótínos přijímal, přesto je jasné, že rozlišoval nižší části duše, které měly blíže k matérii a zajištovaly zprostředkující funkce ve vztahu k našemu tělu, a vyšší části duše, které naopak byly v kontaktu s vyšší metafyzickou úrovní, inteligibilním světem Intelektu. Tato vyšší část duše je pak chápána jako naše nejvlastnější Já, je to pro Plótína naše skutečná duše. ${ }^{4}$

Hlavní spojnicí mezi tělem, resp. nižšími částmi duše a našimi vyššími duševními schopnostmi byla pro Plótína obrazivost $(\varphi \alpha \nu \tau \alpha \sigma i \alpha) .{ }^{5}$ Skrze obrazivost se duše vztahuje na jedné straně $\mathrm{k}$ fyzickým prožitků, pocitům a smyslovým vněmům, na druhé straně umožňuje jejich uchopení rozumem a k Intelektu se vztahující částí duše. Obrazivost má přitom pro Plótína podvojnou povahu, přičemž část zaniká s tělem, část je na těle nezávislá. ${ }^{6}$ Stejně tak racionální praktická činnost, ve které aktivní jednání iniciuje rozum, je nejnižším složkám duše zprostředkována pomocí obrazivosti. ${ }^{7}$ Nejvyšší část duše pak zůstává vždy mimo matérii, jakoby v inteligibilním světě Intelektu ${ }^{8}$ - tuto část duše lze tedy chápat jako ,individuální intelekt", který je obrazem Intelektu jakožto hypostáze. ${ }^{9}$

Myšlení duše se pak odehrává v čase a má podobu přechodu mezi jednotlivými objekty, které jsou předmětem myšlení. Plótínos pro tento typ myšlení používá

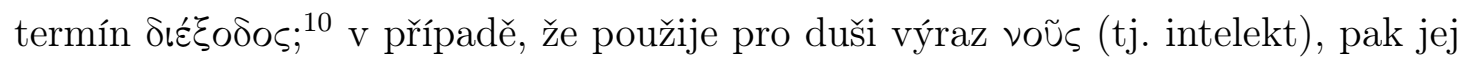

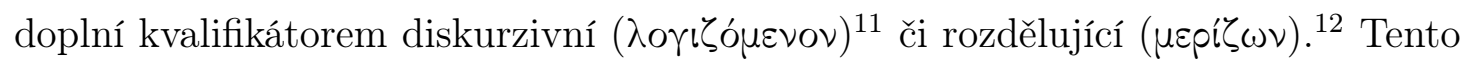
rozumový postup se pak vždy pro Plótína nachází na nižší úrovni než čistý vhled

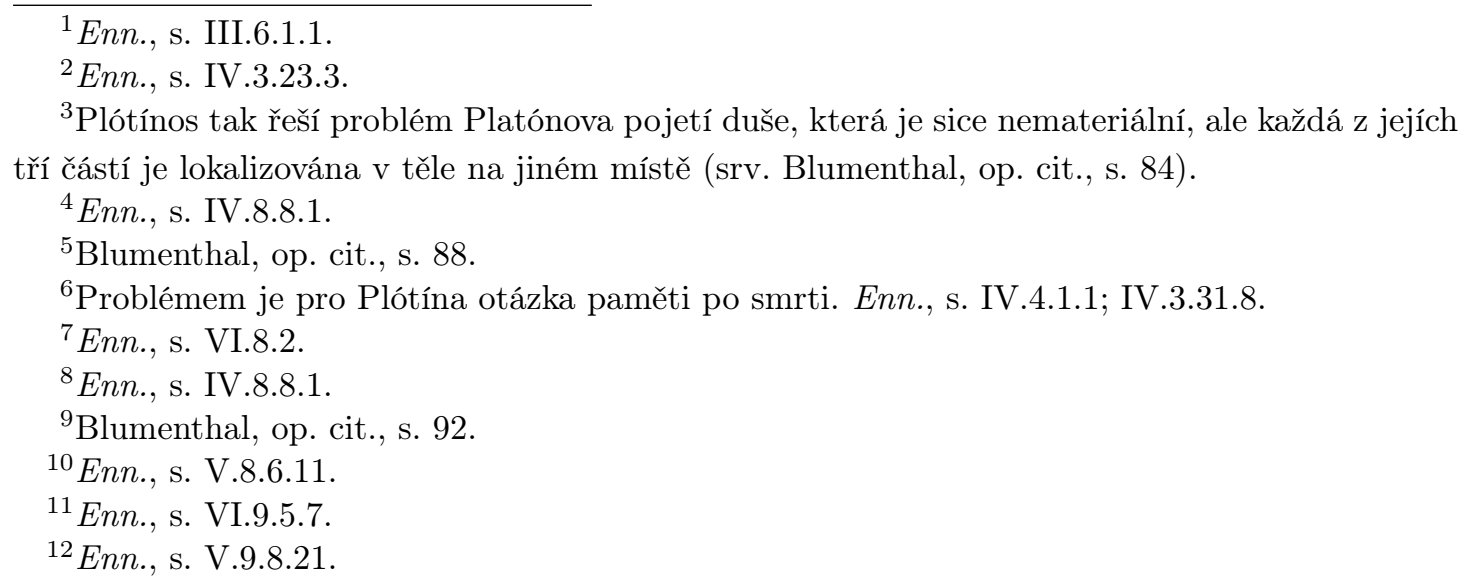


na úrovni Intelektu.

Plótínos se také detailněji než jeho předchůdci zabývá konkrétními myšlenkovými procesy, napřríklad rozpoznáním (xpเveĩ) smyslového objektu jako případu obecného vzoru - tedy situací, kdy rozum musí určit, zdali smyslový předmět, který je mu ve smyslovosti předložen, je případem obecného vzoru, či formy, kterou má již v sobě. ${ }^{1}$ Plótínos přirovnává tento proces $\mathrm{k}$ posouzení rovnosti něčeho pomocí pravítka. $^{2}$ Otázka samozřejmě je, jak je možné smyslové objekty poměřovat čistě inteligibilními vzory, ke kterým má naše duše přístup ve sféře Intelektu. Řešení Plótínos nachází v obrazivosti, která je schopna inteligibilní formu transformovat v ,něco jako“ (oĩov) smyslový obraz, se kterým může rozum dále pracovat. ${ }^{3}$

\section{Nejlepší život, etika, svoboda}

Cílem člověka je pro Plótína žít nejlepší možný lidský život, a takovým životem je život v co největším souladu s Intelektem. Naopak nejnižší části lidské duše jsou ovlivňovány materiálním světem, důsledkem čehož jsou emoce a vášně, které vedou k životu horšímu, jenž není s Intelektem v souladu. Cestu k dosažení nejlepšího

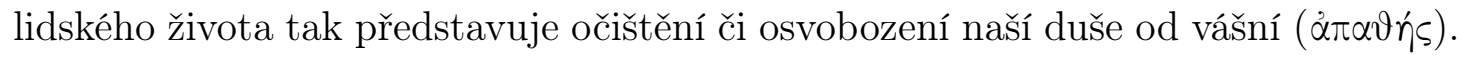
Lidská pozornost by tedy měla být nasměrována na inteligibilní svět Intelektu, a nikoli na materiální svět těles. ${ }^{4}$ Na druhé straně Plótínos přiznává, že nakolik jsme tělesnými lidskými bytostmi, smyslové vnímaní je pro nás podstatnou aktivitou, která je pro naši možnost poznávání nezbytná. Důležité je, aby smyslové vnímání mělo charakter duševní aktivity rozlišování (xpíøı), tedy podporovalo rozlišování forem ve smyslových tělesech a nevyvolávalo vášně. ${ }^{5}$

Plótínos je přitom přesvědčen, že významnou roli v tomto individuálním duchovním rozvoji hraje především odvrácení pozornosti od hmotného světa, který nás neustále rozptyluje řadou zdánlivě naléhavých impulsů, a zaměření této pozornosti na inteligibilní svět Intelektu. ${ }^{6}$ Přestože je toto zaměření velmi obtížné a nesnadno dosažitelné, právě ta část naší duše, která se prolíná se sférou Intelektu, tedy se nachází nad materiálním světem, je podle Plótína naším nejvlastnějším Já. Tím se vracíme k otázce existence individuální formy každého jednotlivého člověka (na úrovni Intelektu), která by vlastně tímto naším nejvlastnějším Já byla. Na jiných místech Plótínova textu se naopak zdá, že za naše nejvlastnější Já považuje střední část duše, spojenou s diskurzivním myšlením. ${ }^{7} \mathrm{~K}$ této otázce se také váže rozsáhlá diskuse v současné odborné literatuře. ${ }^{8}$

\footnotetext{
${ }^{1}$ Enn., s. V.3.2.11, V.3.4.13.

${ }^{2}$ Enn., s. I.6.3.1, VI.7.6.2.

${ }^{3}$ Enn., s. IV.3.30, V.3.2.9.

${ }^{4}$ Enn., s. I.4.10.6, IV.3.30.13.

${ }^{5}$ Enn., s. IV.4.23.

${ }^{6}$ Enn., s. V.3.3.27, IV.3.30.11.

${ }^{7}$ Enn., s. V.3.3.34. Srv. Armstrong, op. cit., s. 261.

${ }^{8}$ Blumenthal, op. cit., s. 100; John M. Rist. "Forms of Individuals in Plotinus". In: Classical Quarterly 13 (), s. 223-231; Blumenthal, Soul and Intelect. Studies in Plotinus and Later Neoplatonism, Ch. IV; John M. Rist. "Ideas of Individuals in Plotinus. A Reply to Dr. Blumenthal". In: Revue Internationale de philosophie 27 (1970), s. 298-303; Arthur Hilary Armstrong. Plotinian
} 
Přes tyto apely, které lze v Enneadách naleznout, Plótínos nepřijímá svobodu vůle v běžném slova smyslu. Svoboda člověka je především věcí právě nejvy̌̌ší části duše, Já, ukotveného v inteligibilním světě. Toto Já je ovšem určováno svou vlastní inteligibilní přirozeností, nelze tedy v jeho případě mluvit o vůli tak, jak je obvykle chápána. ${ }^{1}$ Pokud tedy člověk jedná v souladu s tímto svým nejvlastnějším Já, s plným vědomím a chápáním tohoto jednání, a není ve svém jednání ovlivněn podněty z nižších částí své duše, pak takový člověk jedná v Plótínově pojetí svobodně. ${ }^{2}$ Naopak váhání či rozhodování se mezi různými jednáními je známkou ovlivnění našeho jednání impulsy ze smyslového světa, a je tedy známkou nesvobody. Skutečně svobodné jednání tak probíhá zcela spontánně a automaticky, tím nejlepším možným způsobem. ${ }^{3}$ Důkladnější analýza svobody v Plótínově pojetí jde nad rámec tohoto textu; v této věci můžeme doporučit výklad, který podal ve své monografii F. Karfík. ${ }^{4}$

Na úrovni hypostáze Duše pak existuje také jakási předzjednaná harmonie mezi jednotlivými individuálními dušemi. Plótínos se zde inspiruje Platónovými Zákony: ${ }^{5}$ ovšem na rozdíl Platóna nezakládá toto harmonické uspořádání na prvotním božském rozhodnutj ${ }^{6}$ a včleňuje do této harmonie i vztah mezi jednotlivými dušemi a světovou duší (přrírodou), která pro tyto individuální duše vytváří životní prostředí. $^{7}$

\section{Vzájemný vztah hypostází}

Protože jednotlivé hypostáze produkují méně dokonalé stupně skutečnosti zcela spontánně a zůstávají touto produkcí neumenšeny a nezměněny, jsou také na podřadných stupních skutečnosti zcela nezávislé a nijak se k nim nevztahují. Vyjma

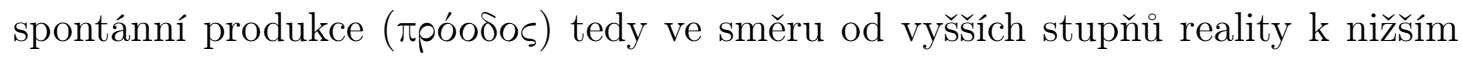
není žádný vztah. Především o Jednom pak Plótínos říká, že nemá žádný vztah ke svým produktům, ba dokonce, že pokud by jeho produkty neexistovaly, nemělo by to něj žádný vliv, stejně jako kdyby naopak z něj vzešel ještě nějaký jiný vesmír. ${ }^{8}$ Plótínovu koncepci tak v žádném případě nelze vykládat jako panteismus, protože jak Plótínos na tomtéž místě říká, pokud by bylo Jedno (Bůh) vším, pak by také bylo na všem závislé. Ovšem Jedno ve svém bytí vše transcenduje, tedy vyprodukovavši vše, co jest, je na všem nezávislé, nižší stupně existence se Jedna nijak nedotýkají, nechávají jej zcela bez jakéhokoli zájmu (lze-li takto metaforicky mluvit) ${ }^{9}$

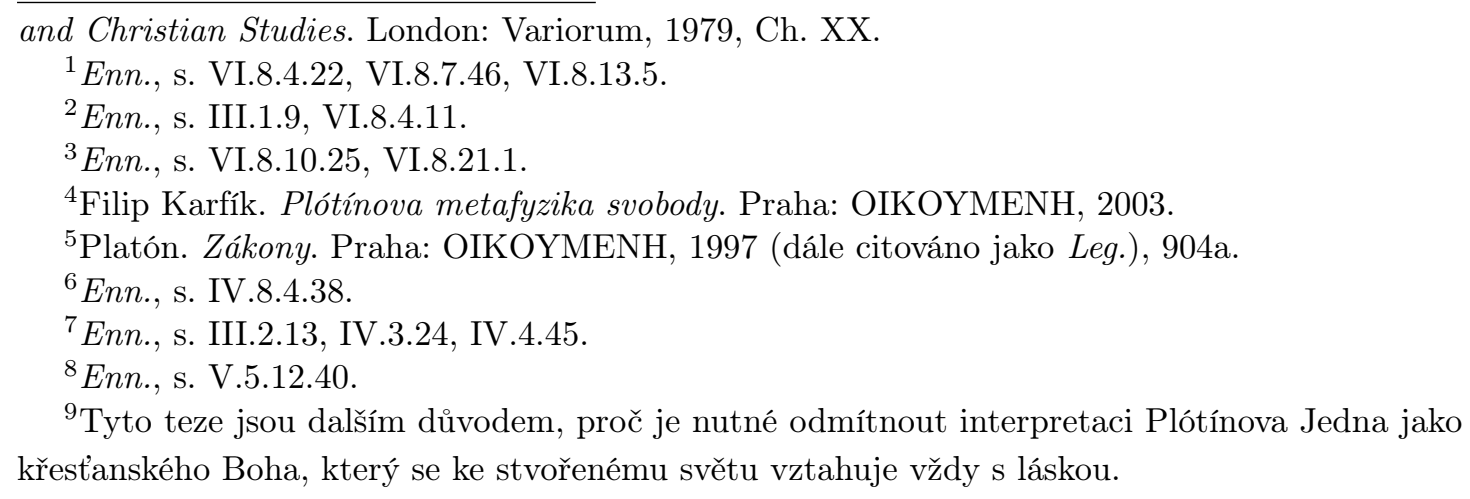


V opačném směru je situace zcela jiná, od nižších stupňů jsoucna k vyšším

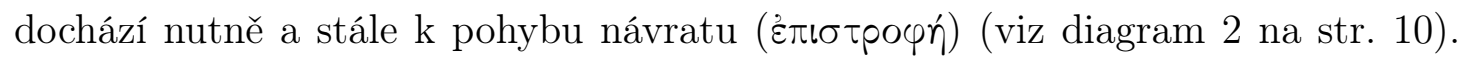
Tento zpětný pohyb, ve kterém se produkt obrací ke svému zdroji, je pak pohybem, ve kterém produkt získává formu a řád. Zároveň pak Plótínos s ohledem na

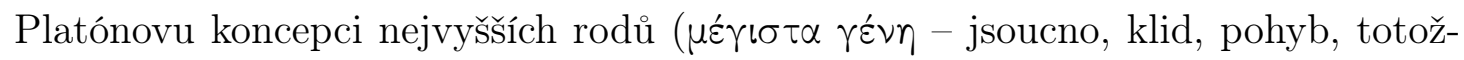
nost, různost $)^{1}$ přiřazuje $\mathrm{k}$ produktivnímu toku z Jedna rody pohybu a různosti, zatímco k návratu pak rody klidu a totožnosti (viz diagram 2 na str. 10). Významnou roli v tomto procesu hraje vidění, nebot' vidění smyslového objektu nás může vést $\mathrm{k}$ ideji tohoto objektu, př́padně $\mathrm{v}$ kontemplaci ještě výše. ${ }^{2}$

Žádná z hypostází také nemá „vědění“ o nižších stupních skutečnosti. Jedno je „mimo/za“ jakýmkoli věděním: ${ }^{3}$ Intelekt je ve stavu věčné kontemplace svých vlastních neměnných principů, a nemůže se tak ve svém myšlení jakkoli vztahovat k v čase proměnnému světu nižších úrovní skutečnosti. Jediným kandidátem na vědění o nižším stupni reality tedy zůstává Duše. Zde Plótínos říká pouze tolik, že světová duše „vî“ jen o kosmickém dění v jeho celku, co se týče jeho principů, nikoli v jeho konkrétní podobě. ${ }^{4}$ Pro Plótína přitom toto nevědění hypostází o nižších úrovních skutečnosti nepředstavuje jejich nedostatek, nebot' ty mají v sobě vždy vyšší typ vědění, tudíž absence nedokonalého obrazu tohoto vědění, tak jak je přítomen na nižší úrovni skutečnosti, nelze za nedostatek pokládat. ${ }^{5}$

Vzájemný vztah hypostází hraje u Plótína roli i při vysvětlování paranormálních fenoménů. ${ }^{6}$ Jelikož je svět (mimo temnou masu matérie) živoucím organismem, události v jedné jeho části vyvolávají odezvy v ostatních částech. ${ }^{7}$ Například modlitba k božským bytostem sice nemůže ovlivnit jejich ve věčné kontemplaci pohroužené vědomí na úrovni Intelektu, ovšem jejich nižší části duše ovlivnit může, a tak může i dosáhnout splnění vymodlené žádosti. ${ }^{8}$ Stejně tak vysvětluje Plótínos vztah mezi vnitřním morálním charakterem duše jednotlivce a obrazem tohoto charakteru, který lze vyčíst v jeho očích, a vztah mezi osudem člověka a pohybem hvězd. ${ }^{9}$ Tato souvislost se však vztahuje jen na nižší části lidské duše, nejvyšší, na úrovni Intelektu existující část lidské duše je na hvězdných pohybech nezávislá a v tomto ohledu svobodná. ${ }^{10}$ Stejně tak všechny magické praktiky, na které Plótínos věřil, pracují pouze na úrovni nižších částí duše, nejvyšší část duše je jimi nedosažitelná a nedotknutelná. ${ }^{11}$ Nejvyšší Já člověka tedy tyto praktiky nemohou ohrozit, ovšem ani mu nemohou v jeho duchovním úsilí pomoci. ${ }^{12}$ Tyto Plótínovy názory jsou v kontrastu s praktikami pozdního neoplatonismu, který se od filosofie

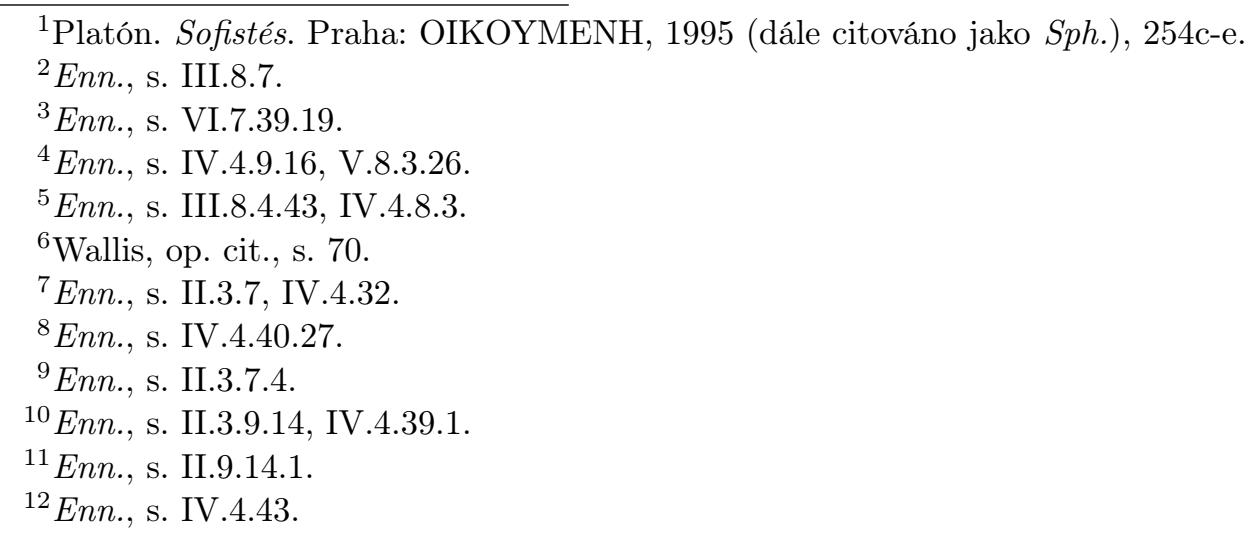


odklonil k theurgickým rituálům. ${ }^{1}$

\begin{tabular}{l|lll}
\hline Jedno & jednota & - & - \\
Intelekt & mnohost & věčnost & - \\
Duše & - & časovost & bezrozměrnost \\
Hmota & - & - & rozprostraněnost \\
\hline
\end{tabular}

Tabulka 1: Ontologické diference hypostází.

Podíváme-li se nyní na vztahy hypostází, jak jsou vyjádřeny v tabulce 1, můžeme říci, že na úrovni každé z hypostází vstupuje do ontologického rozvrhu nová metafyzická dimenze. Na úrovni Intelektu je založena mnohost, na úrovni Duše čas, na úrovni hmoty prostor. Tyto dimenze pak prostupují i na nižší ontologické úrovně, k nižším hypostázím, ovšem v pozměněné podobě. Ke vztahu Intelektu a Duše vzhledem k mnohosti Plótínos říká, že Intelekt je jednotou v mnohosti (عís

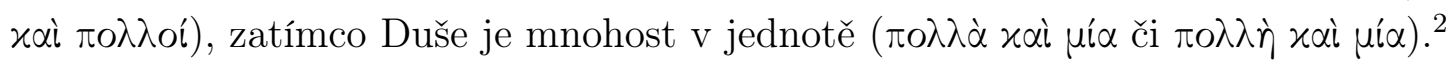

Čas se objevuje až na úrovni Duše. Intelekt je věčný, tj. mimo jakýkoli čas ne jen trvající v každém okamžiku. ${ }^{3}$ Oproti tomu Duše je $v$ čase, i když existuje vždy, tj. v každém okamžiku času, její existence je s časem svázána.

Rozdíl mezi bezčasým myšlením Intelektu a časovým myšlením Duše u Plótína jsme již zmínili na straně 13. Intelekt své objekty, ideje nazírá v bezčasé kontemplaci, Duše oproti tomu myslí diskurzivně, v propozicích, sylogisticky, strukturovaně.

Nyní si snadno uvědomíme, že na úrovni Jedna a Intelektu není možno mluvit v časových výrazech, jejich existence má charakter bezčasé věčnosti, stejně tak Duše, ač jejím vstupem je na scénu přiveden i čas, je sama jakožto hypostáze také věčná. Tedy Plótínos chápe svět jako věčně existující - a to i svět smyslový, tudíž výklad, který nalézáme v Platónově dialogu Timaios, kde se popisuje časově určený vznik smyslového světa, není možné brát podle Plótína doslova. ${ }^{4}$

\section{Závěrečné poznámky}

Celou Plótínovou metafyzickou stavbou prochází několik základních myšlenek či principů, které nesou její základní konstrukci a zároveň mohou sloužit jako interpretační klíče k otázkám, jež mohou čtenáře napadat, pokud se některými obtížnějšími částmi tohoto díla chce zabývat. O několika těchto principech jsme se již zmínili - ty zde můžeme zopakovat a také upozornit na některé další.

Základním principem celé Plótínovy metafyziky je princip jednoty v mnohosti. Stejně jako je celek univerza svou základní strukturou kontrapozicí Jedna a mnohosti, tak i v rámci každé z hypostází je základním pořádajícím principem nějaká

\footnotetext{
${ }^{1}$ Srv. Philip Merlan. "Plotinus and magic". In: Isis XLIV.4 (pros. 1953), s. 341-348; Arthur Hilary Armstrong. "Was Plotinus a magician?" In: Phronesis I I (1955), s. 73-79.

${ }^{2}$ Enn., s. VI.9.1.39, IV.8.3.10.

${ }^{3}$ Enn., s. IV.4.1.25.

${ }^{4}$ Enn., s. III.2.1.20, IV.3.9.12, VI.7.3.1.
} 
rozrůzněná mnohost, tvořící ovšem v určitém ohledu jednotu. Intelekt je jak mnohostí jednotlivých forem, tak i jejich jednotou. Duše je mnohostí jednotlivých duší, světové duše a jejich jednotou konstituovanou společnou formou univerzální duše. Stejně tak svět smyslových forem ve své různorodosti tvoří ve výsledku jednotu.

Dalším takovým principem je, že produkované je vždy nedokonalým obrazem produkujicího, přesto (či právě proto) lze produkujícího (nedokonale) poznávat z produktu. ${ }^{1}$ Pro Plótína je tento princip zřejmě axiomem vycházejícím z pozorování nedokonalosti ve světě a nutnosti tuto nedokonalost vysvětlit. ${ }^{2}$ Způsobem jak jej vysvětlit je pak umístění dokonalých vzorů, prvních věcí, do sféry Intelektu: „O každé první věci platí, že smysly ji vnímat nelze, nebot' idea ve věcech přístupných smyslům je jen obrazem pravého jsoucna na látce; každá idea, která je na něčem jiném, do něho vstoupila z něčeho dalšího, čeho je obrazem. “3

Specifickým principem Plótínova myšlení je všudypř́tomnost života. Celé universum tvoří jeden velký organismus, ${ }^{4}$ na vyšší úrovni se jedná o Intelekt, který je živoucím celkem živoucích forem, podobně je to i na úrovni Duše. Beztvará temná smyslová matérie je sice neživá, ovšem my se s ní setkáváme vždy už jako se zformovanou přírodou, které tvar dává bezpochyby živá světová duše. Stejně tak o Jednu nemůžeme sice říci, že je živé, ale ani že je neživé, pro nemožnost připisovat mu jakékoli charakteristiky odvozené z nižších úrovní existence, přesto však, podle principu, že produkované je nedokonalým obrazem producenta, můžeme usuzovat, že i Jedno je v jakémsi vyšším smyslu navýsost živé.

\footnotetext{
${ }^{1}$ Wallis upozorňuje, že Plótínos nikde nevysvětluje, proč produkt musí být vždy méně dokonalý než producent (Wallis, op. cit., s. 60)

${ }^{2}$ Srv. Proclus. The elements of theology. Oxford: Clarendon Press, 1963 (dále citováno jako Proklos. ET.), Proposition 7.

${ }^{3}$ Enn., s. V.9.5.17, překl. P. Rezka upravil autor - عíôs překládáme jako idea.

${ }^{4} \mathrm{Na}$ tomto místě můžeme připomenout doktrínu „kosmické sympathie" ( $\left.\sigma \cup \mu \tau \alpha \dot{v} \vartheta \varepsilon ı \alpha\right)$ - organického propojení veškerého kosmického dění, spojenou se jménem stoika Poseidónia (135-51 př. n. 1.)
} 


\section{Literatura}

Aristotelés. Fyzika. Překl. A. Křřž. Praha: Nakladatelství Petr Rezek, 1996.

- Metafyzika. Překl. A. Křřž. Praha: Nakladatelství Petr Rezek, 2003.

- O duši. Překl. A. Křǐž. Praha: Nakladatelství Petr Rezek, 2000.

Armstrong, Arthur Hilary. Plotinian and Christian Studies. London: Variorum, 1979.

— "Plótínos". In: ed. A. H. Armstrong. Praha: OIKOYMENH, 2002.

— "Was Plotinus a magician?" In: Phronesis I I (1955), s. 73-79.

Blumenthal, Henry J. "On soul and intellect". In: The Cambridge Companion to Plotinus. Ed. Lloyd P. Gerson. Cambridge: Cambridge University Press, 1996.

- Soul and Intelect. Studies in Plotinus and Later Neoplatonism. Aldershot: Variorum, 1993.

Bussanich, John. "Plotinus's metaphysics of the One". In: The Cambridge Companion to Plotinus. Ed. Lloyd P. Gerson. Cambridge: Cambridge University Press, 1996.

Corrigan, Kevin. Reading Plotinus : A Practical Introduction to Neoplatonism. West Lafayette: Purdue University Press, 2005.

Gerson, Lloyd P., ed. The Cambridge Companion to Plotinus. Cambridge: Cambridge University Press, 1996.

Irwin, Terence H. Aristotle's First Principles. Oxford: Clarendon Press, 1988.

Karfík, Filip. Plótínova metafyzika svobody. Praha: OIKOYMENH, 2003.

Lloyd, Anthony C. Form and Universal in Aristotle. ARCA: Classical and Medieval Texts, Papers and Monographs 4. Liverpool: Francis Cairns, 1981.

Lovejoy, Arthur O. The Great Chain of Being. Harvard University Press, 1936.

Merlan, Philip. "Plotinus and magic". In: Isis XLIV.4 (pros. 1953), s. 341-348.

O'Meara, Dominic. "The hierarchical ordering of reality in Plotinus". In: The Cambridge Companion to Plotinus. Ed. Lloyd P. Gerson. Cambridge: Cambridge University Press, 1996.

Platón. Listy. Praha: OIKOYMENH, 1996.

- Sofistés. Praha: OIKOYMENH, 1995.

- Timaios. Praha: OIKOYMENH, 2008 (2014).

- Ústava. Praha: OIKOYMENH, 2005.

- Zákony. Praha: OIKOYMENH, 1997.

Plótínos. Sestry duše. Praha: Nakladatelství Petr Rezek, 1995.

Plotinus. Enneads I-VI. Překl. A. H. Armstrong. Loeb Classical Library. Cambridge, Massachusetts: Harvard University Press, 1966-1988.

Porfyrios. "Vita Plotini". In: Plotinus. The Enneads. London: Larson Publications, 1992.

Proclus. The elements of theology. Oxford: Clarendon Press, 1963.

Rezek, Petr, ed. Jednotliviny a individuální formy. Praha: OIKOYMENH, 1993.

Rist, John M. "Forms of Individuals in Plotinus". In: Classical Quarterly 13 (), s. $223-231$. 
M. Vacura Základní struktura Plótínovy metafyziky

Rist, John M. "Ideas of Individuals in Plotinus. A Reply to Dr. Blumenthal". In: Revue Internationale de philosophie 27 (1970), s. 298-303.

Vacura, Miroslav. "Systém kategorií u Aristotela". In: E-LOGOS (2009), s. 1-22.

Wallis, Richard T. Neoplatonism. London: Hackett Publishing, 1972. 


\section{E-LOGOS}

ELECTRONIC JOURNAL FOR PHILOSOPHY

Ročník/Year: 2013 (vychází průběžně/ published continuously)

Místo vydání/Place of edition: Praha

ISSN 1211-0442

Vydává/Publisher:

Vysoká škola ekonomická v Praze / University of Economics, Prague

nám. W. Churchilla 4

Czech Republic

13067 Praha 3

IČ: 61384399

Web: http://e-logos.vse.cz

Redakce a technické informace/Editorial staff and technical information:

Miroslav Vacura

vacuram@vse.cz

Redakční rada/Board of editors:

Ladislav Benyovszky (FHS UK Praha, Czech Republic)

Ivan Blecha (FF UP Olomouc, Czech Republic)

Martin Hemelík (VŠP Jihlava, Czech Republic)

Angelo Marocco (Pontifical Athenaeum Regina Apostolorum, Rome, Italy)

Jozef Kelemen (FPF SU Opava, Czech Republic)

Daniel Kroupa (ZU Plzeň, Czech Republic)

Vladimír Kvasnička (FIIT STU Bratislava, Slovak Republic)

Jaroslav Novotný (FHS UK Praha, Czech Republic)

Jakub Novotný (VŠP Jihlava, Czech Republic)

Ján Pavlík (editor-in-chief) (VŠE Praha, Czech Republic)

Karel Pstružina (VŠE Praha, Czech Republic)

Miroslav Vacura (executive editor) (VŠE Praha, Czech Republic) 